Babylonian Encounters in the Upper Diyala River Valley: Contextualizing the Results of Regional Survey and the 2016-2017 Excavations at Khani Masi

Author(s): Claudia Glatz, Jesse Casana, Robin Bendrey, Emma Baysal, Daniel Calderbank, Francesca Chelazzi, Francesco Del Bravo, Neil Erskine, Mette Marie Hald, Elise Jakoby Laugier, Eric Jensen and Elsa Perruchini

Source: American Journal of Archaeology, Vol. 123, No. 3 (July 2019), pp. 439-471

Published by: Archaeological Institute of America

Stable URL: https://www.jstor.org/stable/10.3764/aja.123.3.0439

JSTOR is a not-for-profit service that helps scholars, researchers, and students discover, use, and build upon a wide range of content in a trusted digital archive. We use information technology and tools to increase productivity and facilitate new forms of scholarship. For more information about JSTOR, please contact support@jstor.org.

Your use of the JSTOR archive indicates your acceptance of the Terms \& Conditions of Use, available at https://about.jstor.org/terms 


\title{
Babylonian Encounters in the Upper Diyala River Valley: Contextualizing the Results of Regional Survey and the 2016-2017 Excavations at Khani Masi
}

\author{
CLAUDIA GLATZ, JESSE CASANA, ROBIN BENDREY, \\ EMMA BAYSAL, DANIEL CALDERBANK, FRANCESCA \\ CHELAZZI, FRANCESCO DEL BRAVO, NEIL ERSKINE, \\ METTE MARIE HALD, ELISE JAKOBY LAUGIER, ERIC \\ JENSEN, AND ELSA PERRUCHINI
}

\begin{abstract}
Kassite Babylonia counts among the great powers of the Late Bronze Age Near East. Its kings exchanged diplomatic letters with the pharaohs of Egypt and held their own against their Assyrian and Elamite neighbors. Babylonia's internal workings, however, remain understood in their outlines only, as do its elite's expansionary ambitions, the degrees to which they may have been realized, and the nature of ensuing imperial encounters. This is especially the case for the region to the northeast, where the Mesopotamian lowlands meet the Zagros piedmonts in the Diyala River valley and where a series of corridors of movement intersect to form a strategic highland-lowland borderland. In this paper, we present critical new results of regional survey in the Upper Diyala plains of northeast Iraq and excavations at the Late Bronze Age site of Khani Masi. Not only do our data and analyses expand considerably the known extent of Babylonia's cultural sphere, but also the monumental character of Khani Masi and its wider settlement context prompt a fundamental rethinking of the nature and chronology of Babylonian presence in this transitional landscape. As such, this paper contributes an important new case study to the field of archaeological empire and borderland studies. ${ }^{1}$
\end{abstract}

\section{INTRODUCTION}

Kassite Babylonia (ca. 1550-1150 B.C.E.) was one of the great powers of the Late Bronze Age, an international age in which the expansive polities of

American Journal of Archaeology Volume 123, Number 3

July 2019

Pages 439-71

DOI: $10.3764 /$ aja.123.3.0439

www.ajaonline.org

\footnotetext{
${ }^{1}$ We would like to thank the General Directorate of Antiquities of the Kurdistan Region of Iraq and the Garmian Department of Antiquities for allowing us to work in this important area and for their ongoing support. In particular we must thank Abwbakr Osman Zainadin (Mala Awat), Director General of Antiquities and Heritage for the Kurdistan Region, and Shwkr Muhammed Haydar, Director of Antiquities and Heritage for Garmian. In Garmian, we owe a special debt of gratitude to Salah Muhammad Samin, Deputy Director of the Museum, and our representatives during fieldwork, Nawzad Latif, Ahmed Ismail, Jamal Muhamed, Sawat Hambden, Muhamad Ali, and Awat Baban. We thankJakob Lauinger for reading and commenting on parts of this manuscript. Funding for fieldwork has been provided by the British Institute for the Study of Iraq, The Carnegie Trust for the Universities of Scotland, the G.A. Wainwright Fund, the John Robertson Bequest (University of Glasgow), the Leverhulme Trust (IAF-2014-019), the Center for Middle East Studies at the University of Arkansas, Dartmouth College, and the U.S. National Science Foundation (1724488).
} 
Anatolia, Egypt, Elam, and Mesopotamia exchanged diplomatic gifts and letters, entered into marriage alliances, and schemed and fought against one another in a complex game of international chess with wellknown dramatis personae. ${ }^{2}$ By contrast, Babylonian cuneiform sources, while numerous, lack the annalistic texts of other contemporary imperial networks and therefore permit only a crude sketch of Kassite dynastic succession, the tenets of Babylonia's political organization and economy, and its ruling elite's expansionary aspirations. Standard historical narratives see the Kassites as an ethnic group that originated somewhere in the Zagros Mountains. They are first attested in early second-millennium B.C.E. sources as military specialists serving in the armies of King Hammurabi (1792-1750 B.C.E.) and his successors. ${ }^{3}$ In the tumultuous period leading up to the end of Hammurabi's dynasty, increasing conflict with the Kassites is mentioned in Old Babylonian sources. The year names of Samsuiluna (1750-1712 B.C.E.) of Babylon and Rim-Sin II of Larsa, for instance, describe them as "the enemy, the evildoer, the Kassites from the mountains, who cannot be driven back to the mountains."

Following Babylon's capture by Hittite Great King Mursili I in 1595 B.C.E., 5 a Kassite dynasty took control of Babylon, from where it ruled Mesopotamia for more than 400 years. The Kassite ruler Agum II (ca. 1525 or 1500 B.C.E.) seemingly staked a first political claim $^{6}$ over the Diyala River valley, a tributary of the Tigris to the northeast of Babylonia, and the adjacent Zagros piedmonts (fig. 1). ${ }^{7}$ This region forms the focus of this paper. A few generations later, an inscription by Ulam Burariaš, the grandson of Agum II, appears to

\footnotetext{
${ }^{2}$ Liverani 2001; Bryce 2003; Podany 2012; Charpin 2019.

${ }^{3}$ For recent discussions, see Paulus 2014a; Brinkman 2017; van Koppen 2017.

${ }^{4}$ Stol 1976, 54; Charpin 2004, 339-40; Paulus 2011, 2.

${ }^{5} \mathrm{Chronology}$ remains a contested question in this period. Alternative dates are 1651 B.C.E. (long chronology), 1531 B.C.E. (short chronology; Gasche et al. 1998), and 1499 B.C.E. (ultrashort chronology; Hallo 1957-1971); see Manning et al. 2016 for a recent discussion supporting the middle chronology.

${ }^{6}$ Brinkman 1976, 95-7; for a recent translation, see van Koppen 2006.

${ }^{7}$ The Lower Diyala region stretches from the river's confluence with the Tigris to the Jebel Hamrin, which is generally referred to as the "Middle Diyala." The term "Upper Diyala" is here used to describe the river and its adjacent landscapes from the Jebel Mirwari in the south to the Qara Dag range in the north.
}

place him on the throne of the Sealand, ${ }^{8}$ a breakaway kingdom in southern Mesopotamia and the Gulf region, and marks the start of a process of reintegration of regions to the south of Babylon.

The archaeological record of the late second millennium B.C.E. has by and large not been harnessed to address the complexities of Kassite imperial production and local encounters. Prioritizing the question of Kassite origin and purported foreignness, studies of Middle Babylonian architecture and material culture have been concerned mainly with the tracking of cultural continuities from the preceding phase. Past scholarship has interpreted such continuities as a sign of the willing adoption by the Kassite newcomers of Mesopotamia's superior civilization. ${ }^{9}$ Alternatively, some studies have focused on a handful of material traits thought to be true innovations of the time, such as the carved $\mathrm{ku}$ durru stelae and the elaborate molded-brick facades of Middle Babylonian temples, the most famous of which today is the facade of the Inanna Temple at Uruk. ${ }^{10} \mathrm{Ce}$ ramic studies to date have foregrounded typological characterization for chronological purposes and the compilation of distribution maps. ${ }^{11}$ Thought to represent cohesive cultural as well as political zones, the distribution of Late Bronze Age Babylonian ceramic traits has been taken to support the idea of Kassite control over much of the western Zagros. ${ }^{12}$

Such generic conjectures of political control from ambiguous textual and scant archaeological records, however, ultimately tell us very little about what we really want to know: what was the nature of Babylonia's political and cultural relationship with the Zagros and its transitional landscapes? This includes the strategies and materials through which the Babylonian political formation attempted to produce, and reproduce, its sovereignty over more distant locales and the successes and failures of these attempts. Equally significant is the endeavor to identify the responses of local populations to imperial intervention, the degrees of their collaboration and acquiescence, and the social and cultural spheres in which rejection was practiced. Only from

\footnotetext{
${ }^{8}$ Brinkman 1976, 318.

${ }^{9}$ Lloyd 1943; Zadok 1978; Sassmannshausen 1999; Paulus 2011.

${ }^{10}$ Seidl 2017, 327; now reconstructed in the Pergamon $\mathrm{Mu}-$ seum, Berlin.

${ }^{11}$ See, e.g., contributions in Sternitzke et al. 2017; also Armstrong and Gasche 2014.

${ }^{12}$ Pons and Gasche 2006; Fuchs 2017.
} 


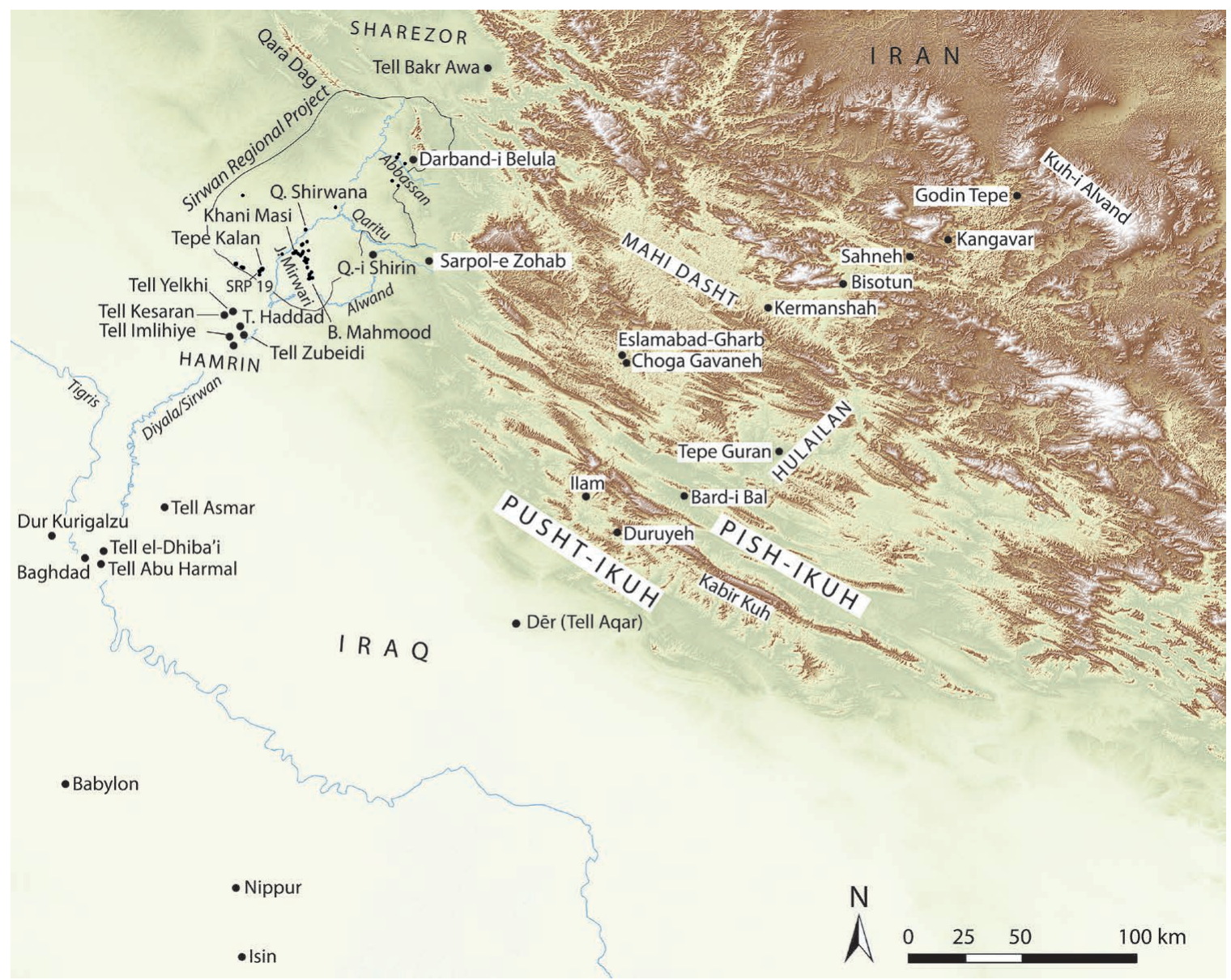

FIG. 1. Map showing key sites mentioned in the text.

the combination of imperial and local perspectives can we reconstruct the complex interplay of agendas and agentive potentialities that shaped both local encounters and the history of the imperial network at large. To begin to answer these questions, a multipronged and contextual archaeological approach is needed, along with a conceptual shift that sees cultural regions and political ones not as coherent, monolithic, and above all congruous things but as complex webs of associations in a constant state of re-formation. ${ }^{13}$

Exploring these questions has become a central research focus of the Sirwan Regional Project (SRP), an international collaboration between Dartmouth College, the University of Glasgow, and the Kurdistan Regional Government Directorate of Antiquities. SRP is dedicated to investigating the archaeological landscapes of the Upper Diyala (Kurdish Sirwan) region

\footnotetext{
${ }^{13}$ E.g., Glatz 2009, 128.
}

through a combination of regional and site-based approaches. In this paper, we present critical new data and our evolving interpretations of ongoing work at the site of Khani Masi. The site's material culture places it at the northern edge of an expanded central Mesopotamian cultural realm, while its monumental architecture identifies it as an important regional center from the 15th to at least the late 13th to early 12th centuries B.C.E. (see fig. 1). ${ }^{14}$

Not only do the results presented in this paper expand the boundaries of the Middle Babylonian cultural realm to include the Upper Diyala plains but also the nature of the newly discovered sites in this strategic transitional landscape fundamentally transforms our understanding of the northeastern borderlands of the Kassite empire. More broadly, the data

\footnotetext{
${ }^{14}$ For earlier reports, see Glatz and Casana 2016; Casana and Glatz 2017.
} 
and interpretations presented here provide a first step toward formulating a new and hitherto largely unexplored case study in early imperial encounters and investigating the social and cultural dimensions of highland-lowland transitional zones.

In this article, we review the textual and archaeological evidence available to date for the political and cultural relationships between Late Bronze Age central Mesopotamia and the Diyala River valley. This is followed by a discussion of emergent regional settlement patterns along the upper reaches of the river and the results of ongoing excavations at Khani Masi. We conclude with a contextualization of our results within the wider historical and archaeological framework of the period, proposing a number of adjustments needed for writing a more nuanced narrative of Babylonia's cultural and political experience in the Diyala River valley.

\section{IMPERIAL AMBITIONS}

A small number of chronologically dispersed textual sources bear witness to Kassite imperial ambitions toward the Diyala River valley and the adjacent western Zagros and suggest motivations that were a mixture of economic interest and international realpolitik. ${ }^{15}$ At stake was control over the critical long-distance routes later known as the Achaemenid Royal Road, the Great Khorasan Highway, and the medieval Silk Route that connected Mesopotamia with highland Iran and central Asia beyond. ${ }^{16}$ Along these routes traveled the prestige goods and raw materials, such as tin, lapis lazuli, semiprecious stones, and granite, that fueled Mesopotamia's political economies. The Kassite rulers Kadašman-Enlil I (1374-1360 B.C.E.) and Burnaburiaš II (1359-1333 B.C.E.), for instance, are on record as having sent large quantities of lapis lazuli to their Egyptian counterparts as diplomatic gifts. ${ }^{17}$ The region of Namar was a key supplier of horses, while first-millennium B.C.E. sources also talk of socalled Diyala spice mills, perhaps pointing to the influx of exotic Asian spices. ${ }^{18}$ Late Kassite texts (12th century B.C.E.) mention merchants traveling to the west-

\footnotetext{
${ }^{15}$ For a summary of Kassite sources, see Brinkman 1976; for recent discussions of Kassite presence and activity in the Upper Diyala and western Zagros, see Fuchs 2017; van Koppen 2017.

${ }^{16}$ Liverani 2011, 376; Steinkeller 2013.

${ }^{17}$ E.g., Amarna Letters EA7 and EA9; Moran 1992, 12-16, $18-20$.

${ }^{18}$ Dalley 1985; Kuhrt 1995, 341-43; Radner 2003, 38-43; 2014; Fuchs 2011, 2017.
}

ern Zagros (Lullubum), while the servile population at 14th- and 13th-century B.C.E. Nippur included a wide range of foreigners, among them Elamites, Lullubeans, and men from Ullipi, modern Lurestan, some of whom were captives of war. ${ }^{19}$

Potentially the earliest Kassite Babylonian political claim over the Lower and Upper Diyala and the mountainous regions east along the Great Khorasan Highway may be found in the inscription of Agum II, or Agum-kakrime (ca. 1500 B.C.E.), which asserts his kingship over the "Land of Ešnunna, the Land of Padan and Alman, and the Land of the Gutians." ${ }^{20}$ This inscription is not uncontroversial as, on the one hand, it is preserved in first-millennium B.C.E. copies only and, on the other, some scholars have expressed doubts regarding its authenticity. ${ }^{21}$ In a recent paper, however, Paulus argues that the preserved texts present genuine copies of a Late Bronze Age royal inscription. ${ }^{22}$

Alman, or Halman as it is referred to in Middle Babylonian sources, is generally equated with Sarpol-e Zohab in western Iran (see fig. 1) on the basis of a Late Kassite kudurru inscription that was found near the late third- or early second-millennium B.C.E. Anubanini rock relief. ${ }^{23}$ Puzzling here is that the author of the kudurru text described the Turnat/Turran, the Diyala River, as flowing through the city of Halman. Modern scholars have interpreted this as an ancient geographical misunderstanding, which equated the Holwan or Alwand River, a tributary of the Diyala that flows close to Sarpol-e Zohab, with the upper course of the Diyala rather than the Sirwan farther to the west. ${ }^{24}$ However, it is rather difficult to imagine how one could be mistaken in the identification of the upper course of the Diyala, which presents a much more imposing landscape feature than the Alwand, including at the confluence of the two rivers north of the modern town Jalawla. Thus, the kudurru text could equally mean that a different site along the Upper Diyala or Sirwan was

\footnotetext{
${ }^{19}$ Tenney 2011, 124; Brinkman 2017, 25, 27.

${ }^{20}$ Brinkman 1976, 95-7; for a recent translation, see van Koppen 2006.

${ }^{21}$ Brinkman $(2017,9)$ suggests an ascription to Agum II (ca. 1500 B.C.E); see Paulus 2018 for a summary of the arguments presented by scholars who have questioned the text's authenticity.

${ }^{22}$ Paulus 2018, 117.

${ }^{23}$ Borger 1970, 1.

${ }^{24}$ Borger 1970, 1; Fuchs 2011, 231.
} 
called Halman in this period, a point we return to in our conclusion. ${ }^{25}$

According to a Babylonian oracle question, Padan and Halman were separated by a two-day journey and the Tengurgur pass. ${ }^{26}$ Padan, if it can be equated with the Neo-Assyrian Padnu, may have been located in a relatively lowland position along the eastern bank of the Diyala. ${ }^{27}$ Somewhere between Padan and Halman lay another settlement, the location of which is also unknown, called Dur-Šulgi. The so-called Chronicle P describes the victory of a Kurigalzu ${ }^{28}$ over the Elamite king Hurbatila, who had challenged Kurigalzu, so the story goes, to do battle with him at Dur-Šlgi. ${ }^{29}$ A victorious Kurigalzu claimed several thousand horses as booty from this encounter. ${ }^{30}$

To the east of Halman and Padan along the Great Khorasan Highway lay the land of Namar, or Namri in Assyrian sources. ${ }^{31}$ A literary narrative, also preserved only as a first-millennium copy, recounts the attack on the Land of Namri by the Kassite king Nazi-Maruttaš (1307-1282 B.C.E.),32 who ordered that the temple at Nippur be supplied with beverages from the region. ${ }^{33}$ Western Kermanshah and in particular the mound of Choga Gavaneh, which yielded a substantial architectural complex and an Old Babylonian archive, ${ }^{34}$ have been proposed as candidates for Namar, ${ }^{35}$ although no evidence for a Late Bronze Age occupation has been published from the site. A related toponym, Nikkum, tends to be placed in the region around the modern town of Khanaqin. ${ }^{36}$

Following the deportation of the Kassite ruler Kaštiliašu IV (1232-1225 B.C.E.) by the Assyrian king Tukulti-Ninurta I in 1225 B.C.E., the Elamite ruler Kidin-Hutran II led two military campaigns through this region and appears to have established Elamite

\footnotetext{
${ }^{25}$ See also Paulus 2014b, MAI I4.

${ }^{26}$ Translation in Lambert 2007, 62-7, lines 22-4.

${ }^{27}$ Fuchs 2011, 236 n. 35.

${ }^{28}$ Grayson 1975, 139-41; Brinkman 1976, 207, 418-23; translation in Glassner 2005, 279-81; Fuchs 2011, 241: Kurigalzu I (?-1375 B.C.E.); Paulus 2014a, 71: Kurigalzu II (13321308 B.C.E.).

${ }^{29}$ Fuchs 2011, 232-36.

${ }^{30}$ Glassner 2005, 278-81.

${ }^{31}$ Fuchs 2011, 2017.

${ }^{32}$ See Brinkman 2017, 25.

${ }^{33}$ Legrain 1922, no. 69.

${ }^{34}$ Kordevani 1971.

${ }^{35}$ Abdi and Beckman 2007, 48.

${ }^{36}$ Frayne 1992, 64; Fuchs 2017.
}

control over Padan and Halman. ${ }^{37}$ Once recovered from the Assyrian assault, Babylonia sought to reaffirm its hegemony over Halman and Namar through the gifting of land to Kassite officials. Land grants, often inscribed on kudurru stones, were generous gifts of property, usually upward of 240 ha, especially in the northern and eastern border areas. Included in the grant were the settlements located within the gifted landscapes, whose resident populations and land tenants then paid taxes and supplied labor to the grantee rather than to relevant provincial governors. ${ }^{38}$

Three Kassite provinces ( $p \bar{i}$ hatu) were located in the Diyala region and the adjacent western Zagros: Tupliaš, Namar, and Halman. Tupliaš had provincial status by the end of the 14th century B.C.E. and, contrary to earlier localizations in the Lower Diyala, would seem to be geographically associated with Namar. ${ }^{39}$ Namar and Halman first appear as provinces on the kudurru of Marduk-apla-iddina I (1171-1159 B.C.E.) from Sarpol-e Zohab ${ }^{40}$ and are therefore to be considered a late development and part of a general shift in the geographical focus of land grants to the northern and northeastern perimeters of the Kassite realm. ${ }^{41}$

Unlike the scant Middle Babylonian sources reviewed above, Neo-Assyrian campaign reports from the first quarter of the first millennium B.C.E. paint a much richer, if still one-sided, picture of the western Zagros. Mentioned are several military encounters with people described as Kassites in the region of Namri with some said to have occupied fortified highland towns and others to have lived in tents. Evidence in these texts for local rulers with Kassite personal names, Kassite or Kassite-influenced toponyms, and the worship at some places in Namri and Media of the Mesopotamian gods Marduk, Nergal, and Ishtar well into the first millennium B.C.E. recently prompted Fuchs to ascribe retrospectively much of western Iran-from Qasr-i Shirin east to Eslamabad-Gharb, Kermanshah, Bisotun, and Sahneh to Kangavar and up to the Kuh-i Alvand-to an extended Kassite political sphere. ${ }^{42}$ Such a scenario, however, as we argue below, is not borne out by the archaeological evidence at hand.

\footnotetext{
${ }^{37}$ Liverani 2011, 377.

${ }^{38}$ Paulus 2013.

${ }^{39}$ Roaf 2017.

${ }^{40}$ Borger 1970, 1-11; Seidl 1989, 222, pl. 33.

${ }^{41}$ Paulus 2017, 237; see also Paulus 2014b, NKU I 2.

${ }^{42}$ Fuchs 2017, 145-46.
} 
Archaeological evidence in the form of surface survey and excavations along the lower reaches of the Diyala sketches out a rural settlement pattern whose 13th- and 12th-century B.C.E. estates and villages participated in a wide range of Babylonian cultural practices, including scribal conventions, that point toward at the very least a nominal association with the Late Kassite political realm. The region to the north of the Jebel Hamrin range, which provides access to the fertile Sharezor high plateau to the north and through which several important trade and military routes exit from the Zagros, also shows close cultural connections with Babylonia. The newly discovered sites along the Upper Diyala, however, are substantial urban centers quite different in character to those recorded in the Hamrin, while Late Bronze Age settlements to the north and east show only scant and highly selective cultural connections with the Babylonian realm.

\section{DIYALA SETTLEMENT LANDSCAPES}

Cuneiform texts from the final years of the Old Babylonian period (late 17th and early 16th centuries B.C.E.) suggest a dramatic rupture in settlement and urban life across large parts of Mesopotamia. ${ }^{43}$ However, recent excavations at Tell Khaiber in southern Iraq, an administrative center of the breakaway Sealand Dynasty, have begun to redefine this traditional narrative of urban collapse as one of resilience by demonstrating the continuity of local settlement, localized political institutions, and administrative practices. ${ }^{44}$ A new period of stability is traditionally thought to be signaled by evidence for renewed settlement at, for instance, Nippur, a major religious and commercial center, ca. 1400 B.C.E. The construction of Dur-Kurigalzu, the new Kassite capital at the narrowest point between the Tigris, Euphrates, and Diyala Rivers, followed shortly thereafter, as did a series of ambitious projects of urban renewal and monumental temple construction at almost all major Mesopotamian cities.

Lacking recent systematic excavations against which to date surface collections, the Lower Diyala survey evidence is generally interpreted, in line with the late Old Babylonian textual accounts, to show a sharp decline in the overall density of settlement, the degree of urbanization, and the average size of individual communities

\footnotetext{
${ }^{43}$ Stone 1977; Gasche 1989.

${ }^{44}$ Campbell et al. 2017.
}

from the Old Babylonian period. ${ }^{45}$ Adams also painted a rather bleak picture of the region during the Kassite period, describing it as "a border district astride the routes taken by invading Assyrian and Elamite armies and probably shifting or contradictory in its relations with outside powers." ${ }^{\text {"6 }}$ Settlement organization in this phase comprised a few regional centers, all much reduced in size compared with previous periods, around which clustered small and often newly founded villages such as Tell Abu Harmal and Tell el-Dhiba' i. ${ }^{47}$

The linchpin of Mesopotamian, Elamite, and Assyrian marching routes, however, lay farther north on, for instance, the so-called Elam-Kišma-Dēr-Diyala Road, ${ }^{48}$ where the Diyala River cuts through the Jebel Hamrin, the westernmost Zagros outlier and not far from which exit major overland routes from the Zagros Mountains. This strategic intersection was known as the "lock of the land" in Babylonian sources. ${ }^{49}$

Here, too, settlement numbers diminished from about 20 sites with evidence for occupation during the Old Babylonian period to eight sites during the Late Bronze Age. ${ }^{50}$ There is very little to suggest direct settlement continuity, although some sites overlay significant Middle Bronze Age occupations such as at Tell Yelkhi and Tell Haddad/Tell el-Sib (about 120 ha), ancient Me-Turran. ${ }^{51}$ As in the Lower Diyala, Late Bronze Age sites in the Hamrin are smaller in size than in the preceding period and several are new foundations. The 13th- and 12th-century settlement landscape of the Hamrin also broadly matches that proposed by Adams for the Lower Diyala, with Tell Yelkhi ${ }^{52}$ performing the role of a small regional center amid a scatter of agricultural estates and villages such as Tell Imlihiye and Tell Zubeidi ${ }^{53}$ and industrial sites such as Tell Kesaran. ${ }^{54}$

The occupation sequence at Tell Yelkhi reveals a long-lasting but variable cultural and political relation-

\footnotetext{
${ }^{45}$ Adams 1965, 50-2, 115, table 25.

${ }^{46}$ Adams 1965, 53.

${ }^{47}$ Adams 1965, 53-5, table 14.

${ }^{48}$ Carter and Stolper 1984, 58-60; Frayne 1992.

${ }^{49}$ Steinkeller 1981, 163, with references in n. 3 .

${ }^{50}$ Killik 1988, figs. 6-7; Yaseen 1995, 9-22; Armstrong and Gasche 2014

${ }^{51}$ Muhamed 1992, 23; Al-Rawi 1994; Frayne 2008, 43 and map.

${ }^{52}$ Invernizzi 1980; Bergamini et al. 1985.

${ }^{53}$ Boehmer and Dämmer 1985.

${ }^{54}$ Fiorina 1984.
} 
ship with Mesopotamia. The site's second-millennium B.C.E. occupation includes a sizable settlement dating to the early Isin-Larsa period (level IV, ca. 2004-1763 B.C.E.), whose cuneiform tablets place it in the political sphere of Ešnunna, a powerful kingdom centered on Tell Asmar in the Lower Diyala basin. The following level III is somewhat diminished in scale but yielded a small private tablet archive containing economic texts, contracts, letters, and omen texts. ${ }^{55} \mathrm{~A}$ hiatus in occupation marks the transition to the early Late Bronze Age (level II, 16th century B.C.E.), along with a change in the ceramic tradition that is described as having fewer affinities with Mesopotamia and greater links to the Zagros and Tigris regions. ${ }^{56}$ Cut into the structures of level II is a $40 \times 30 \mathrm{~m}$ architectural complex at the top of the mound with large storage magazines. This structure has been interpreted by the excavators as a palazzo, or governor's residence. ${ }^{57}$ The pottery assemblage in the first occupation phases $(\mathrm{Ib}-\mathrm{c})$ of the palazzo is largely local in character with few typically Babylonian shapes, especially with regard to consumption vessels. ${ }^{58}$ Only in the final phase of level I (Ia) do Middle Babylonian types proliferate. ${ }^{59}$ The dating of the final two occupation levels at Yelkhi is as yet uncertain, with some proposing a 14 th-century date for level $\mathrm{I}^{60}$ and others adhering to the original stratigraphic assessment that places level $\mathrm{Ib}-\mathrm{c}$ in the 15 th13 th centuries and the final level Ia in the 13th-12th centuries B.C.E. ${ }^{61}$

Both Tell Imlihiye and Tell Zubeidi, probably ancient Zaddi/Zaddu, ${ }^{62}$ were small agricultural estates or villages that were established on virgin soil sometime in the 13th century B.C.E. and had close and wide-ranging Babylonian cultural connections. ${ }^{63} \mathrm{Cu}$ neiform tablets from both sites provide glimpses of local economic and administrative practices and local interdependencies; they also mention five consecutive Kassite rulers: Kadašman-Enlil II, Kudur-Enlil,

\footnotetext{
${ }^{55}$ Rouault and Saporetti 1985.

${ }^{56}$ Oselini 2018.

${ }^{57}$ Invernizzi 1980; Bergamini et al. 1985.

${ }^{58}$ Calderbank 2018; Oselini 2018.

${ }^{59}$ Armstrong and Gasche 2014, 11-12.

${ }^{60}$ Gasche et al. 1998, 25; Armstrong and Gasche 2014.

${ }^{61}$ Gentili 2012, 105.

${ }^{62}$ Frayne 2008, 36.

${ }^{63}$ Boehmer and Dämmer 1985.
}

Šagarakti-šuriaš, Kaštiliašu IV, and Enlil-nādin-šumi. ${ }^{64}$ Several uninscribed tablets from Tell Zubeidi point to the presence of scribal personnel at these small sites, while the frequent mention of Kassite rulers suggests at least a nominal political affiliation of the Hamrin with Babylonia at this time. The latest tablet recovered from Tell Zubeidi suggests the survival of its community, the region's wider socioeconomic system, and its likely Kassite political affiliation beyond Tukulti-Ninurta I's invasion of Babylon and the deportation of Kaštiliašu IV in 1225 B.C.E. ${ }^{65}$ Two additional small new foundations of the 12th-11th centuries B.C.E. in the Hamrin area (at Tell Ajamat and Tell Mughir) also show strong ceramic links with central Mesopotamia. ${ }^{6}$

\section{A Northern Perimeter}

About $25 \mathrm{~km}$ north of the Hamrin basin, the SRP has been recording a very different regional settlement pattern than those attested along the river's middle and lower reaches in terms of the number of recorded sites and their large, urban character. Here we found a cluster of substantial, and in several cases newly established, late second-millennium B.C.E. sites in the fertile plains on either side of the Diyala. The sites appear to form a northern perimeter of communities that partook in an extended Babylonian cultural sphere.

They include the 20 ha site of Tepe Kalan (SRP 18), whose lower city is littered with solid-footed goblets and standardized baked bricks (fig. 2). SRP 19 is a nearby 14 ha site with a very similar surface assemblage. At Bawa Mahmood (SRP 184), near the modern town of Khanaqin, we found a baked-brick platform and large quantities of typical Middle Babylonian pottery eroding out from under the modern Islamic shrine and graveyard (fig. 3). A series of low mounds in the Khani Masi site cluster points to a total settled area of at least 40 ha during the Late Bronze Age and a cultural repertoire closely aligned, at first glance at least, with Kassite Babylonia. ${ }^{67}$ Smaller sites, 2.5 ha in size or less, dot the fertile plain east of Khani Masi. The only exception to this, in terms of size, is Qala Shirwana to the north, the extensive, perhaps 100 ha lower city,

\footnotetext{
${ }^{64}$ Kessler 1982, 1985a; Boehmer and Dämmer 1985.

${ }^{65}$ Boehmer and Dämmer 1985, 79-80; Kessler 1985b.

${ }^{66}$ Armstrong 1981a, 1981b.

${ }^{67}$ Work, including geophysics, is still ongoing to ascertain the full extent of late second-millennium B.C.E. occupation at the site.
} 


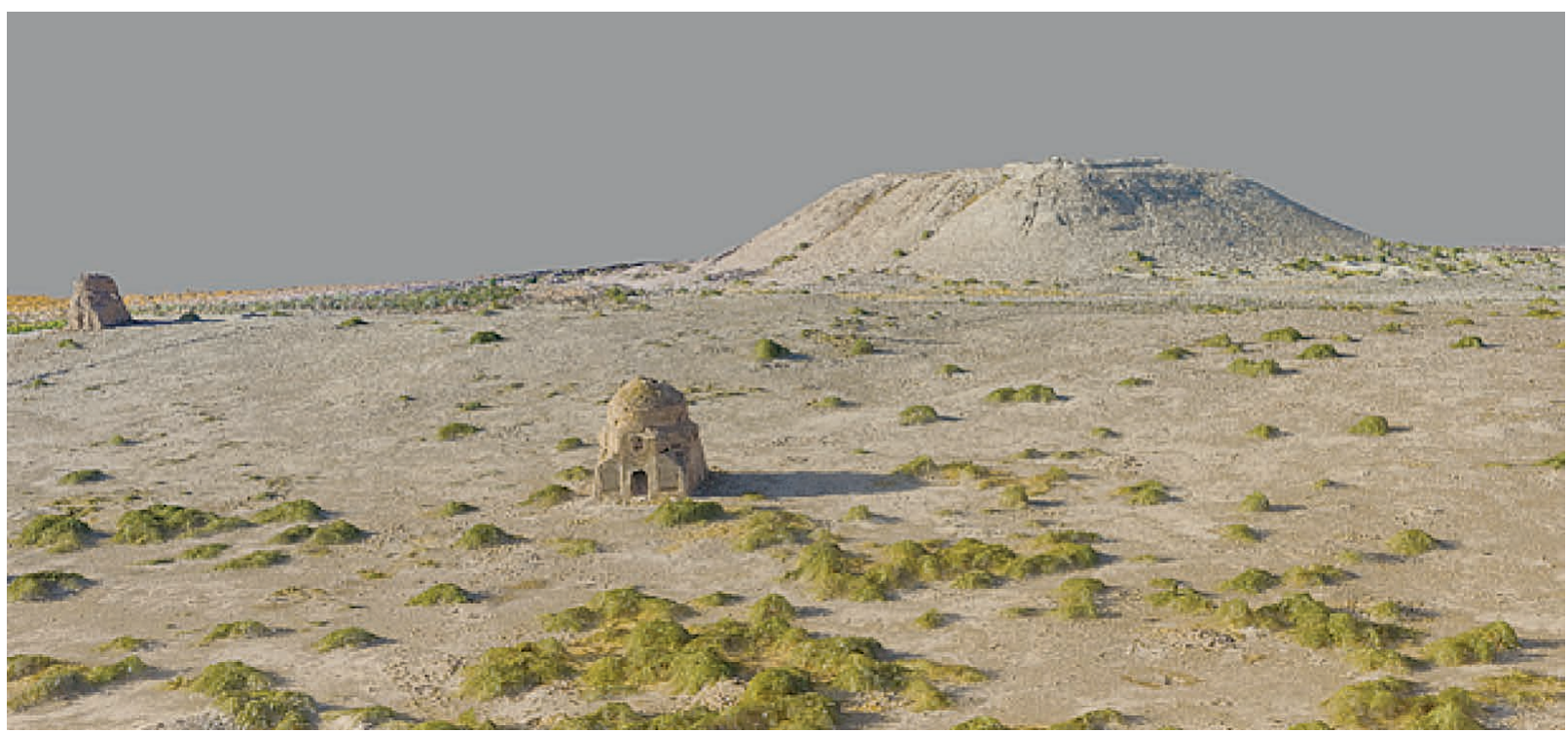

FIG. 2. Photogrammetric model of Tepe Kalan (SRP 18), looking south. The extensive lower city in the foreground yielded large quantities of Late Bronze Age pottery.

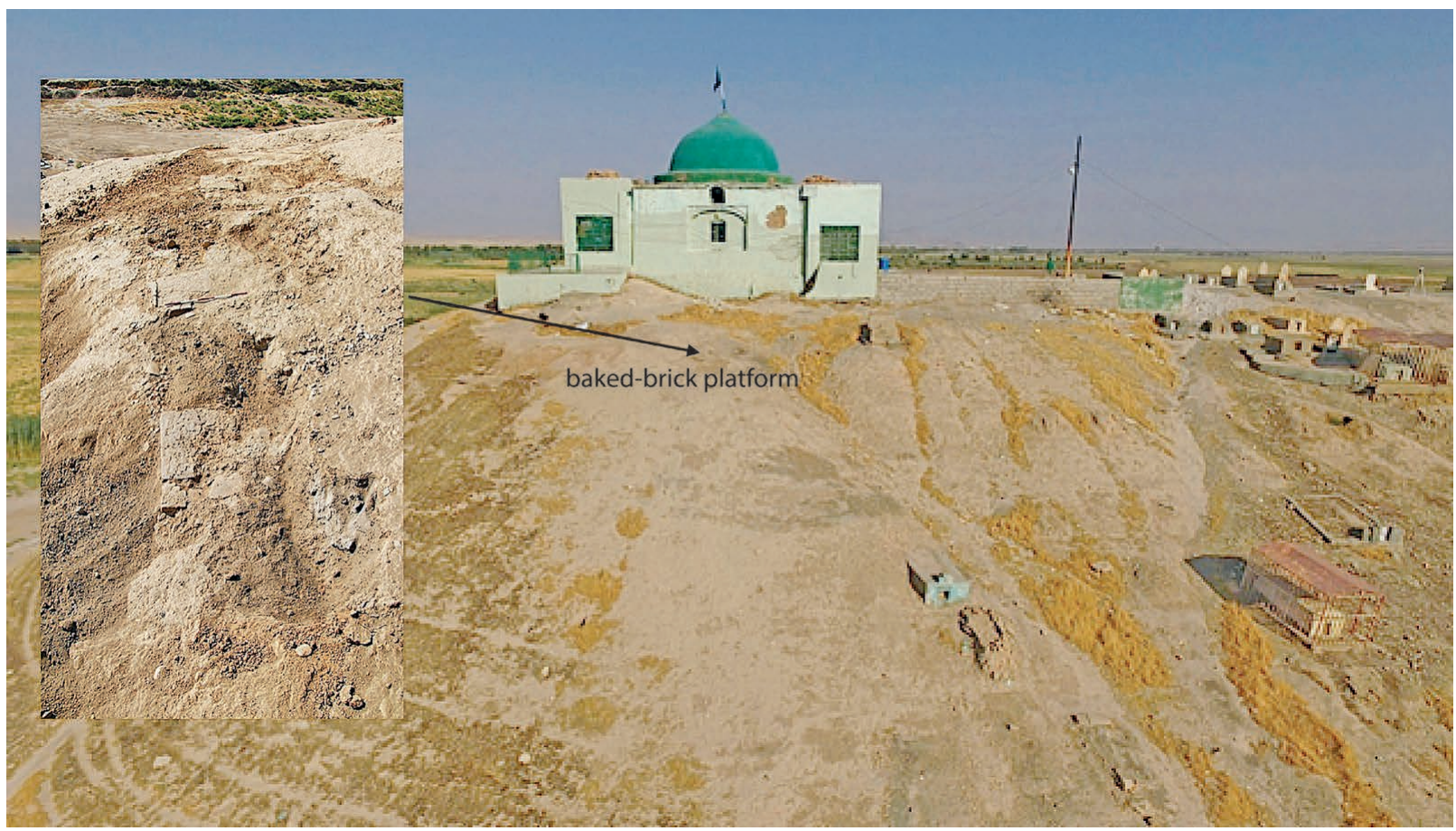

FIG. 3. Photogrammetric model of Bawa Mahmood (SRP 184) and remnants of a baked-brick platform located just below the modern shrine, looking east.

which is now built over by modern Kalar but where construction work regularly turns up solid-footed or Kassite goblets. ${ }^{68}$

${ }^{68}$ Glatz and Casana 2016, 133.
The range and degree of shared Babylonian cultural traits decline sharply at Late Bronze Age sites to the north and east of this perimeter, suggesting a very different relationship and intensity of interaction with Babylonia and the Kassite political sphere. Although the Sharezor is traditionally assumed to have been 
under Kassite Babylonian hegemony, ${ }^{69}$ archaeological evidence for it is scarce. Regional survey recorded only four sites with Mesopotamian pottery types across the high plateau, ${ }^{70}$ and excavations at Tell Bakr Awa yielded only a small number of drinking vessels also attested along the Diyala. ${ }^{71}$ More definitive yet still ephemeral connections can be drawn with western Iran. At Tepe Guran, a small mound, about 1.5 ha, in the Hulailan plain, a range of locally produced Middle Babylonian ceramic types, including several footed goblets, bowls, and jars, was used along with radically different local pottery. ${ }^{72}$ Small drinking goblets, faience buckets, and decorated shell rings typical of Babylonian burial practices were also placed in a number of 13 th- and 12th-century B.C.E. tombs at the Ilam, ${ }^{73}$ Duruyeh, and Bard-i Bal ${ }^{74}$ cemeteries in western Iran.

In order to explore further this striking pattern of large sites with significant Babylonian cultural connections clustered around the Jebel Mirwari, we selected one for further investigation. In the sections below we present the results of three years of large-scale geophysical survey and excavations at Khani Masi along with observations from a range of ongoing material analyses.

\section{THE KHANI MASI SITE CLUSTER}

The site of Khani Masi, which is located $12 \mathrm{~km}$ south of the modern town of Kalar, comprises more than a dozen individual mounded features clustered on the remains of a relict Pleistocene levee of the nearby Diyala River. Today the Diyala flows in a deeply incised, rocky floodplain, forming a network of small river channels separated by islands, and the widening of the floodplain just upriver from Khani Masi served as a natural ford. The site sits at the edge of the Khani Masi plain (Kurdish Bnkura plain), a flat area of approximately $75 \mathrm{~km}^{2}$ that forms one of several flanking basins of the Middle Diyala. Despite its low rainfall, totaling less than $350 \mathrm{~mm}$ per year on average, the plain is a rich agricultural region, as groundwater from the $\mathrm{Za}$ gros Mountains to the northeast emerges in dozens of perennial artesian springs, providing a reliable source of both drinking and irrigation water today as it likely

\footnotetext{
${ }^{69}$ Postgate 1984.

${ }^{70}$ Altaweel et al. 2012, 25.

${ }^{71}$ Miglus et al. 2013, 50-1, fig. 12.

${ }^{72}$ Thrane 1999; 2001, 49-58, figs. 39-44.

${ }^{73}$ Haenrick and Overlaet 2010, 285, 290, fig. 7.

${ }^{74}$ Overlaet 2005, 10-11, pls. 1, 3.3, 3.5, 4.12-14.
}

did in the past. The plain has a dense record of human settlement extending back to the Pre-Pottery Neolithic, largely owing to the springs and the irrigation agriculture they make possible. ${ }^{75}$ Khani Masi, meaning "spring of the fishes," derives its name from one of the larger springs, which emerges in the central plain and flows northwest, draining into the Diyala floodplain. The stream flows through the mounds at Khani Masi today, with perennial water even in the driest months of the year.

Khani Masi was first discovered in 2013 as part of the SRP, ${ }^{76}$ initially identified along with hundreds of other sites through analysis of Corona and modern high-resolution satellite imagery. The largest mounded feature at Khani Masi and the only component of the site known prior to 2014 is Tell Majid (SRP 39), a natural hill with an occupation on top, that rises some $20 \mathrm{~m}$ above the plain (fig. 4). To the north and east of Tell Majid are 14 distinct mounds ranging in size from 1 to 12 ha, with cultural mounding of 1 to $5 \mathrm{~m}$. Several of the mounds on the site (SRP 43, 44, 93, 120) show evidence of occupation during the Halaf period and may have been part of a large, shifting settlement situated around the Khani Masi stream, as has been documented at contemporary sites elsewhere in northern Mesopotamia. ${ }^{77}$ Tell Majid along with SRP 40, 44, and 121 were occupied in the Sassanian and Medieval periods as well. However, the largest settlement at Khani Masi took place during the second millennium B.C.E. SRP 46 is the largest and best-preserved part of the Bronze Age settlement with an area of around 10 ha and rising 2 to $3 \mathrm{~m}$ above the floodplain. The site is covered by a dense concentration of baked bricks and Late Bronze Age pottery, including large quantities of solid-footed or Kassite goblets. Surrounding mounds including SRP 41, 42, 43, 44, 92, 94, 121, 122, the small outlying mound of SRP 95, the lowlying area between SRP 46 and SRP 92, and SRP 189 all show evidence of occupation in the second millennium B.C.E. The area to the southwest of SRP 46 that is today covered by the remains of a military installation is also slightly mounded above the floodplain and may also have been part of the site. While the maximum extent of the Late Bronze Age settlement is as yet difficult to reconstruct owing to modern land use,

\footnotetext{
${ }^{75}$ Casana and Glatz 2017.

${ }^{76}$ Glatz and Casana 2016; Casana and Glatz 2017.

${ }^{77}$ Akkermans et al. 2006.
} 


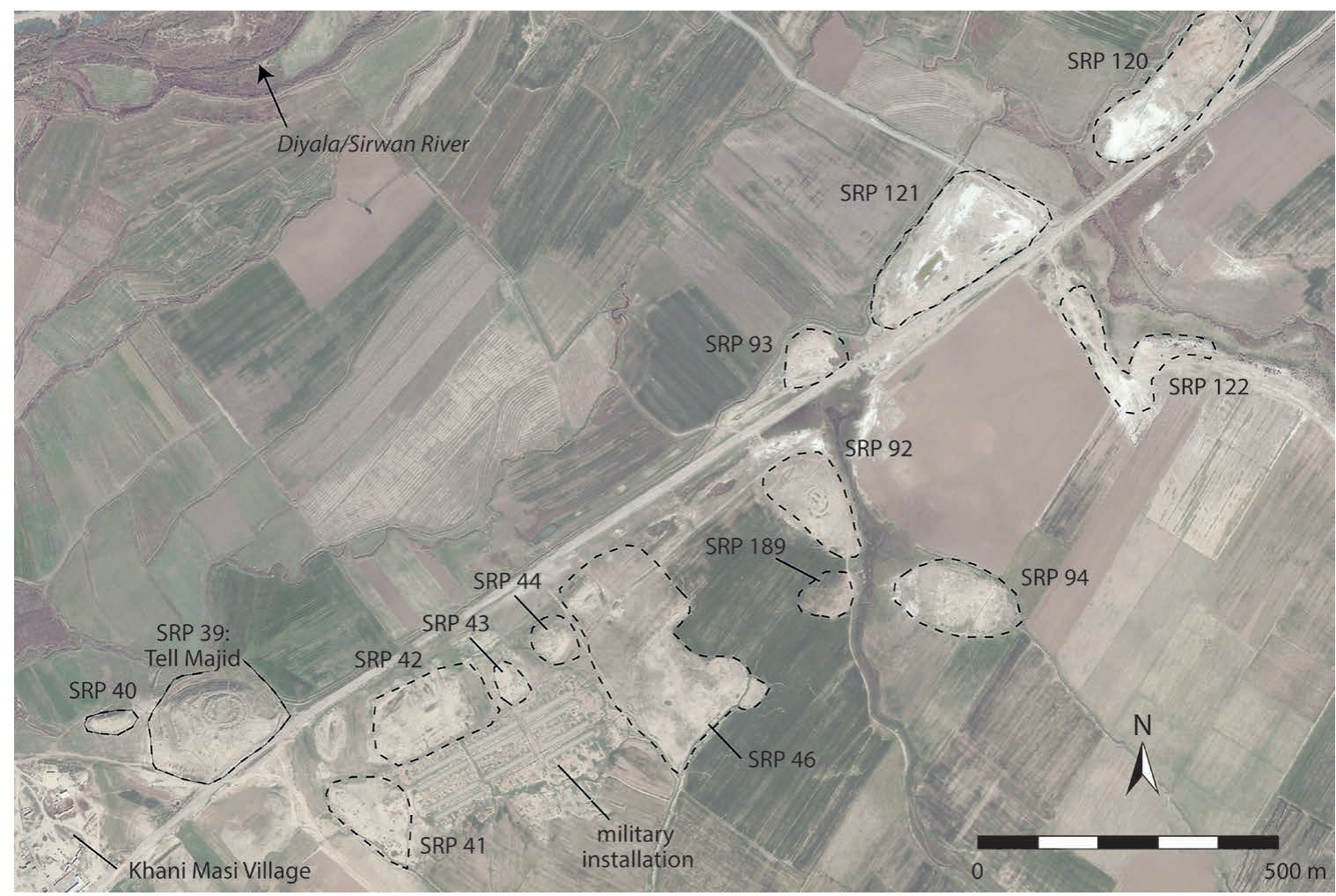

FIG. 4. Satellite image showing the component mounds of the Khani Masi site cluster (2011 GeoEye, (C) DigitalGlobe 2015, modified from Casana and Glatz 2017, fig. 7).

and the precise occupational history at several Bronze Age mounds is still unresolved, it is clear that the late second-millennium B.C.E. settlement at Khani Masi was quite large, covering as much as $40 \mathrm{ha}$.

The modern village of Khani Masi is located about $200 \mathrm{~m}$ southwest of the archaeological site, but the main part of the site itself was impacted by a histori$\mathrm{cal}$ road that traversed through the mounds. Much of the site was then damaged during the 1980s and later, when it became part of a sizable military compound. A series of concrete barrack foundations were laid over the central portion of the site while Tell Majid and SRP 94 were both fortified with trenches. The military use of the site also resulted in other damage including some earthmoving, several large pits, and construction of a new road. Today, however, the site has returned to predominantly agricultural use, with low-lying areas irrigated and more elevated parts of the site annually seeded with wheat, which in wet years can produce a harvest but is otherwise used for grazing cattle and sheep.

\section{GEOPHYSICAL SURVEY}

To gain a better understanding of the extent and character of the Bronze Age settlement at Khani Masi, we undertook magnetic gradiometer survey along with analysis of drone-acquired color and thermal imagery. Magnetic gradiometer survey was begun in 2014 across the extensive and largely late secondmillennium B.C.E. occupation at SRP 46 (see fig. 4$)^{78}$ and was continued in 2016-2017 at several mounds to the northeast (SPR 94, 95) as well as at low-lying areas between them (SRP 189). Magnetic surveys were conducted using a Bartington GRAD-601 dualaxis fluxgate gradiometer in $20 \times 20 \mathrm{~m}$ grids in an east-west direction with $0.5 \mathrm{~m}$ spacing at 8 samples per meter. To date, approximately 9 ha of the site have been surveyed. To complement magnetic survey, we also conducted several surveys using color aerial and thermal imagery, results of which are less revealing of

\footnotetext{
${ }^{78}$ Glatz and Casana 2016.
} 
archaeological features owing to the arid soils at the time of the surveys. ${ }^{79}$

Results of the magnetic gradiometer survey reveal a wealth of architectural features and activity areas across the central part of the site, and these data have largely guided excavations. At SRP 46, a series of prominent, tightly speckled dipolar anomalies is organized in a rectilinear fashion across the southern end of the site. Excavations show that these features are the remains of a monumental building complex, very near the surface, constructed using baked mudbrick, which has been badly damaged and partially destroyed by mechanized plowing in recent years (fig. 5[A]). On the same alignment, we excavated earlier mudbrick structures, including the sequence of buildings excavated in trench Y88 (see fig. 5[B]). To the northwest, a large trapezoidal building complex appears clearly on the magnetic data, inside of which are several strong dipolar anomalies (see fig. 5[C]). Excavations show that these features are kilns and ovens. On the western side of the site, there is a tall, mounded feature, the highest point at SRP 46. Magnetic data show a likely baked-brick rectangular architectural feature inside the mound (see fig. 5[D]). Just to the northeast, there is another square building with interior rooms, partially obscured by numerous strong dipolar anomalies, which we excavated in 2016. Many other architectural and pyrotechnic features are visible across SRP 46 and show that, for at least part of its occupational history, it was densely occupied.

The results of the 2017 magnetic survey in the lowlying area between SRP 46, SRP 92, and SRP 94 also show nearly continuous occupation on this part of the site. Several buildings and other anomalies are visible in this area, extending some $250 \mathrm{~m}$ northeast of SRP 46. One of the most evident is a large building measuring $25 \times 25 \mathrm{~m}$ on a side, with rows of square $5 \times 5$ $\mathrm{m}$ rooms flanking a central courtyard (see fig. $5[\mathrm{E}]$ ). Given the nature of the buildings in this area, it appears likely that it represents a residential neighborhood also dating to the Late Bronze Age.

Magnetic data from the top of SRP 94 several hundred meters to the northeast of SRP 46 show little in the way of architectural features. Numerous high-value anomalies appear that may be ovens, kilns, or even metal objects, but the architecture on this part of the site is not resolvable in magnetic data, though excava- tions revealed the architectural remains of several early second-millennium B.C.E. houses.

\section{EXCAVATIONS}

Excavations at Khani Masi began in 2014 with a $1 \mathrm{x} 4 \mathrm{~m}$ test trench to confirm the site's suspected Late Bronze Age date. A program of large-scale excavations was initiated in the summer of 2016 and was followed by a second season of excavations in the summer of 2017 (fig. 6). The primary aims of the first two seasons of excavations were to expose some of the large-scale architectural features identified by the magnetic gradiometer survey and to begin to reconstruct the site's settlement history, function, and cultural milieu. To date we have uncovered Late Bronze Age occupation in seven trenches over a total area of $655 \mathrm{~m}^{2}$ and to a depth of more than $2 \mathrm{~m}$ in places. Late Bronze Age occupation is generally reached between about 15 and $50 \mathrm{~cm}$ below the current surface, which shows only minimal evidence for later use.

Following test excavations in 2014, we proposed that Khani Masi had a single major phase of occupation followed by a destruction horizon and a less substantial reoccupation. ${ }^{80}$ This first impression can now be revised and replaced with a more complex and long-term urban history in light of the 2016 and 2017 seasons and will no doubt further evolve in the coming years. For now, we can confidently identify five phases of activity across SRP 46. They include a first phase of large-scale architecture that is characterized by the use of unbaked mudbrick walls (phase 1); a phase of industrial reinterpretation (phase 2); a series of ritual depositions both to close and to commemorate buildings and industrial areas (phase 3); an activity phase in which building techniques and the logistics of construction underwent a dramatic transformation, with a shift toward the extensive use of baked bricks in the construction of several large buildings (phase 4); and a final phase of occupation characterized by the small-scale reuse of baked bricks, tannurs, and tombs (phase 5). Some of these phases, especially phase 1 , include a series of sub- or rebuilding phases. It is not possible at this stage to securely establish the synchronicity of phases across all trenches. Given the continuously evolving nature of settlement spaces, in particular those constructed with mudbrick, it is also likely that activities here defined

\footnotetext{
${ }^{80}$ Glatz and Casana 2016.
}

\footnotetext{
${ }^{79}$ Casana et al. 2017.
} 


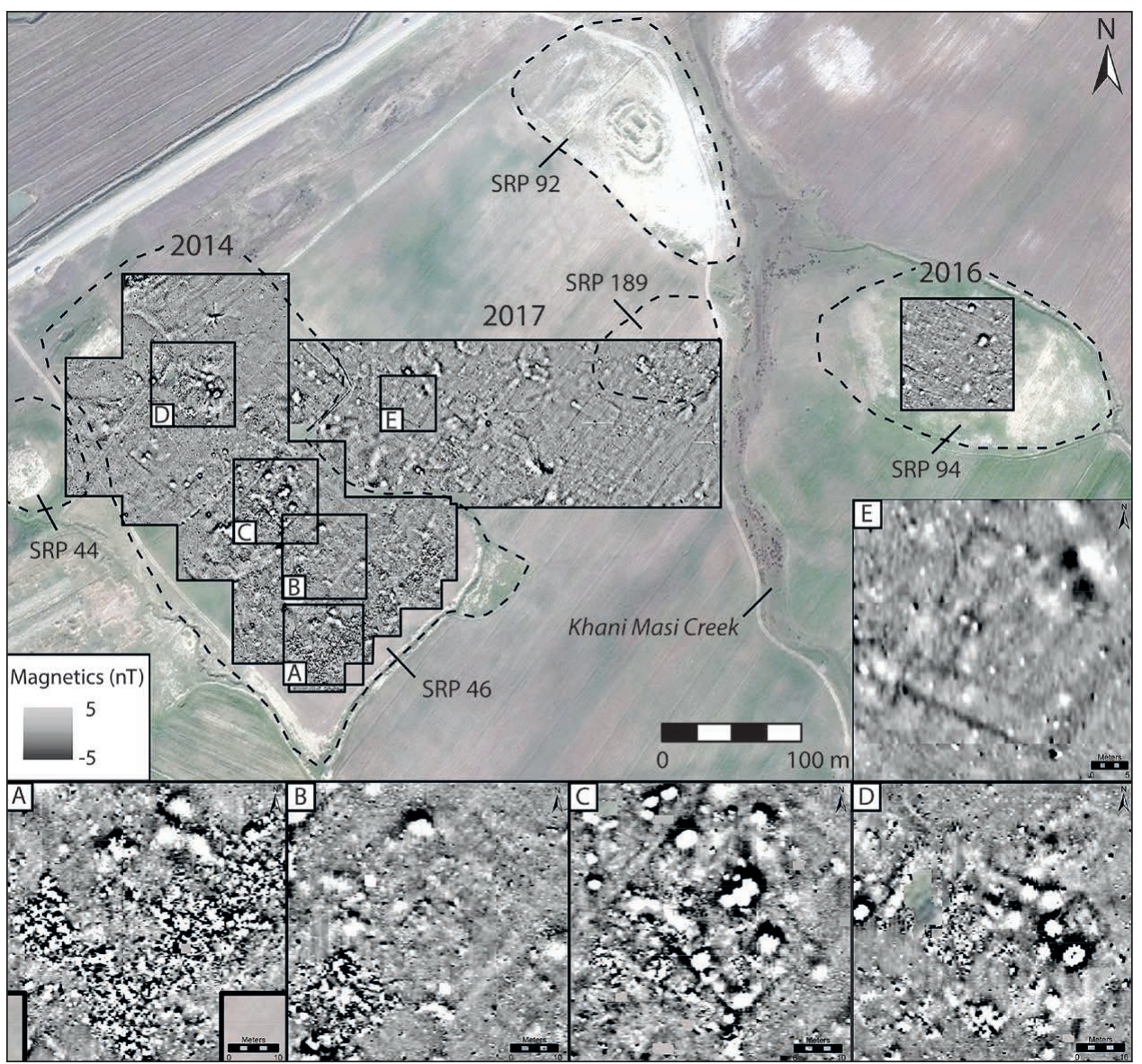

FIG. 5. Results of the magnetometry surveys at SRP 46 in 2014 and 2017.

as phases may partly overlap in time as different areas of the site moved through phases 1-3 at varying paces.

\section{Phase 1: Unbaked Mudbrick}

A Monumental Structure at the Center of the Mound (Trench Y88). In phase 1, several large, and in some cases monumental, structures were built at Khani Masi using unbaked mudbrick and mudbrick packing on what appears to be virgin soil. This includes a large (about $30 \times 40 \mathrm{~m}$ ) walled courtyard complex with a cluster of rooms along its northeastern side (see fig. 5[B]). Excavations in trench Y88, with a 15 $\mathrm{x} 10 \mathrm{~m}$ exposure, have revealed to date four trapezoidal rooms on either side of a mudbrick wall (Wall 1), about $80 \mathrm{~cm}$ thick, that runs diagonally from northeast to southwest (fig. 7). Also exposed was part of what may have been the central courtyard. An external wall, which separates the suite of rooms from the internal courtyard, measures about $1.20 \mathrm{~m}$ in width (Walls 4 and 5), while smaller, internal walls have a width of about $.40 \mathrm{~m}$ (Wall 2). The largest, central Room 1 measures about $4 \times 6 \mathrm{~m}$ and was exposed almost in its entirety. It is flanked by the smaller Room 5 to the east, three excavated rooms (Rooms 2-4) to the west and southwest, and the likely courtyard to the south; another room in the southwest corner of the trench awaits excavation.

The earliest building and occupation phase of this structure was identified in a small $(1 \times 1 \mathrm{~m})$ sounding in the southeast corner of Room 1 in the form of a hard floor and ashy destruction horizon. Finds from the floor include a perforated white stone object as well as fragments of pottery coated with bitumen. Below the floor was encountered a mostly clean soil horizon, which was excavated to a depth of about $50 \mathrm{~cm}$ below the burnt layer.

Following what appears to have been a destruction by fire, a second building phase (seen in the orthoimage in fig. 7) involved a series of architectural modifications, whose full extent remains to be explored. 


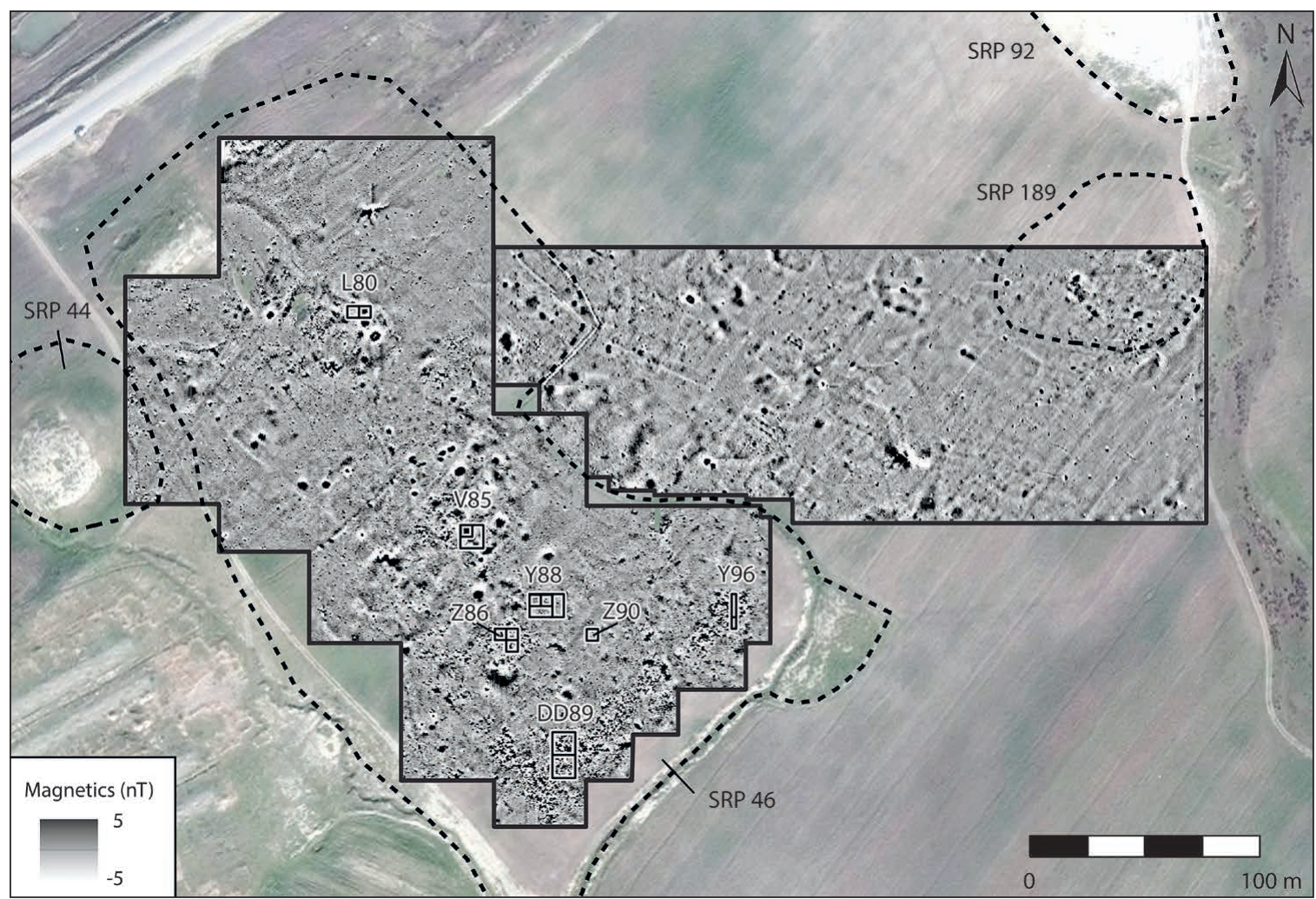

FIG. 6. Location of trenches on SRP 46 in 2016 and 2017.
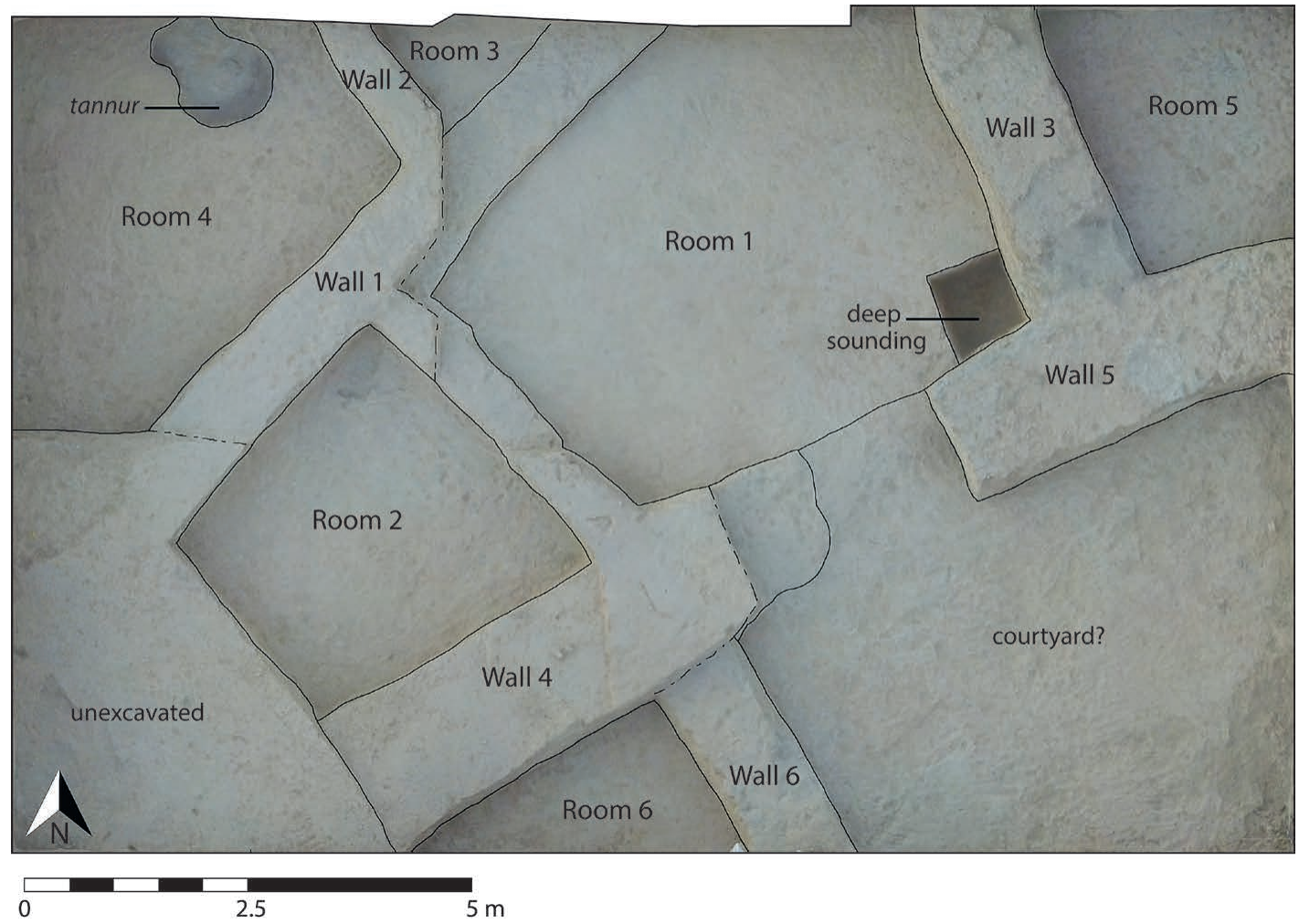

FIG. 7. Annotated orthoimage of the unbaked mudbrick building from phase 1 in trench Y88; the image shows the structure's second building phase. 
What caused the end of this second building is also not clear. There is some evidence of burning in Room 5, but there is no evidence of burning in any of the other rooms or the courtyard area. The building appears to have been cleared out before its walls collapsed or were deliberately toppled for rebuilding. The fill layer of mudbrick collapse above the clearly identifiable, hardpacked, and bluish-green-colored floors contained only small amounts of pottery fragments. Fragments of hard and dense mudbrick-like material with a layer of hardened white plaster in the collapse rubble suggest a second story. A double-chambered tannur in the northern section of Room 4 was also in use during this phase. The absence of small finds across the exposed rooms makes it difficult as yet to determine the function of the structure. The building's overall size, which is comparable to the so-called governor's palace at Tell Yelkhi, however, suggests an important and most likely public or elite function.

A third building phase generally followed the preceding plan, with the exception of the widening of the southern entrance to Room 1 and a possible cutting of an entrance passage between Rooms 1 and 2 . The remnants of a curved drain bordered by parallel lines of baked bricks, each broken in half or into smaller pieces, were exposed in the southwestern part of Room 1 (fig. 8). Floor surfaces and a collapse layer just above were littered with small drinking vessels, larger footed goblets, and other consumption-related vessels, pointing to a locale for commensal consumption. This is confirmed by organic residue analyses of a selection of drinking and serving vessels from this collapse layer. The analyses have identified a combination of compounds consistent with barley beer in several solid-footed or Kassite goblets and an array of smaller drinking vessels. ${ }^{81}$ To the west and northwest, Rooms 2, 3, and 4 yielded cooking installations, faunal remains, and additional drinking equipment as well as a metal pin and decorated shell and bone fragments; these rooms may have had a primary function in food preparation. A charcoal sample from Room 1 dates the sealed materials under the collapse layer to between cal B.C.E. 1415 and $1290(2 \sigma)$ (table 1).

The pottery recovered from the monumental structure in Y88 and all other excavation areas on SRP 46 in phases 1-3 is typical of the Middle Babylonian tradition, which is typologically conservative, showing

\footnotetext{
${ }^{81}$ Perruchini et al. 2018.
}

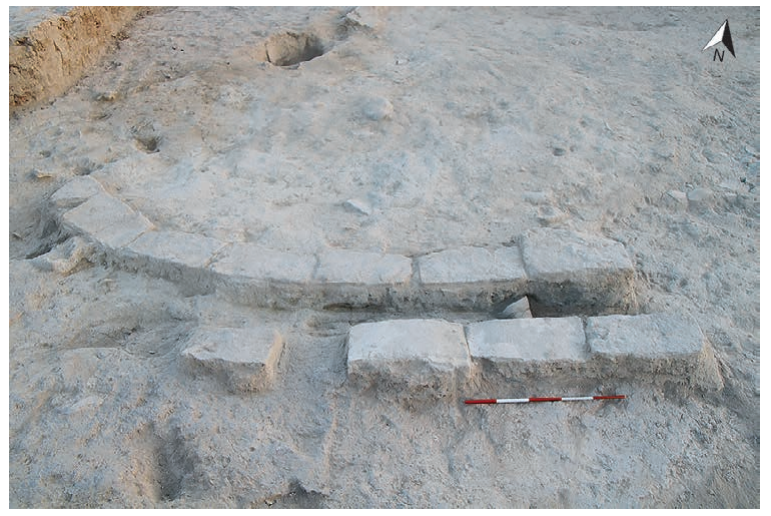

FIG. 8. Drain lined by baked bricks in trench Y88, Room 1 . The channel was constructed during the building's third building stage in phase 1 .

limited development over time (ca. 1500-1150 B.C.E.) (fig. 9). The assemblage is composed of a limited set of shapes and fabrics, with most vessels fired evenly to a yellow-green color, which generally corresponds to a high firing temperature. Smaller tablewares exhibit a wider range of colors (pink, cream, and buff) corresponding to a range of firing temperatures. ${ }^{82}$ Although fine mineral inclusions are present naturally in most vessel fabrics, the most common additive was chaff. As a general rule, larger vessels contain higher concentrations and larger-size chaff temper, which would most likely have aided plasticity during forming and prevented the formation of catastrophic cracks during drying and firing. ${ }^{83}$ Only cooking pots demonstrate the deliberate addition of angular mineral temper, which served to enhance thermal shock resistance.

The most common vessel shapes in the assemblage are goblets and cups, such as those found in concentration in Y88. Goblets (see fig. 9, nos. 21-25) are present in a range of sizes, from impractically tall, steep-sided shapes to squatter, more rounded vessels. Goblets possess a typical elongated foot that forms a stable disc base. Cups (see fig. 9, nos. 1-4, 11-14) generally have a rounded body shape, but base and neck shapes show a good degree of diversity. Bases usually consist of a shaped, flaring foot and are narrower than typical goblet bases. Cup bases are sometimes pedestaled and neatly finished, and are sometimes also flat and with shallow indentation. Necks of cups are usually short but are occasionally tall and ostentatious, ending in

\footnotetext{
${ }^{82}$ After Duistermaat 2008, 45, table II.2.

${ }^{83}$ van As and Jacobs 2014; Glatz and Casana 2016.
} 
TABLE 1. Accelerator mass spectrometry radiocarbon dates from charcoal samples from SRP 46 and SRP 94.

\begin{tabular}{|c|c|c|c|c|c|}
\hline Lab No. & $\begin{array}{l}\text { Conventional } \\
\text { Radiocarbon } \\
\text { Date (uncali- } \\
\text { brated BP) }\end{array}$ & $\begin{array}{c}\text { Calibrated } \\
\text { Date (B.C.E. } \\
[2 \sigma])\end{array}$ & $\delta^{13} \mathrm{C}(\%)$ & Provenience & Period \\
\hline $\begin{array}{l}\text { SUERC-76927/ } \\
\text { GU46587 }\end{array}$ & $3576 \pm 24$ & $2020-1880$ & -26.9 & $\begin{array}{l}\text { SRP 94, trench K136, } \\
\text { locus 6/lot } 3\end{array}$ & $\begin{array}{l}\text { Late Ur III (2112-2004 } \\
\text { B.C.E.)-Isin Larsa } \\
\text { (2003-1895 B.C.E.) }\end{array}$ \\
\hline $\begin{array}{l}\text { SUERC-77188/ } \\
\text { GU46930 }\end{array}$ & $3189 \pm 27$ & $1505-1416$ & -25.4 & $\begin{array}{l}\text { SRP 46, trench V85, } \\
\text { locus } 175 / \operatorname{lot} 2\end{array}$ & Middle Babylonian \\
\hline AA109181/X31274 & $3088 \pm 20$ & $1415-1290$ & -26.8 & $\begin{array}{l}\text { SRP 46, trench Y88B, } \\
\text { locus 20/lot } 30\end{array}$ & Middle Babylonian \\
\hline $\begin{array}{l}\text { SUERC-53433/ } \\
\text { GU34603 }\end{array}$ & $3058 \pm 27$ & $1408-1233$ & -27.2 & SRP 46, test trench 2 & Middle Babylonian \\
\hline
\end{tabular}

rims that are invariably simple, rounded, and slightly flaring, to allow for the pouring of liquid contents. Bowls (see fig. 9, nos. 5-10) are common in two main shapes: straight-sided and carinated. While goblets vary considerably in size and volume, bowls tend to be restricted in size, with rim diameters usually falling between 10 and $16 \mathrm{~cm}$. Large jars are oval to baggy in shape, with a defined neck (see fig. 9, no. 29). Jar rims consist of thickened bands, usually square or triangular; more infrequently they also exhibit a grooved finish. Large vats (see fig. 9, no. 28), or pithoi, have squat, open shapes and vast capacities. Applied ring bases are most common among these vessels, but thickened, perforated bases are also occasionally attested. The latter base type is often associated with the filtering of contents during beer brewing. ${ }^{84}$ Hole-mouth cooking pots, with simple rounded or squared rims and squat, bulbous bodies, are rarely preserved. Cylindrical vessels (see fig. 9, nos. 26, 30) with flat bases, often identified as grain measures, ${ }^{85}$ are found occasionally, and cylindrical pot stands also occur in small numbers.

Most of the shapes attested at Khani Masi are common in the late 13 th- and 12 th-century B.C.E. assemblages of nearby Tell Yelkhi, phase Ia-c, ${ }^{86}$ Tell Zubeidi, and Tell Imlihiye. ${ }^{87}$ Furthermore, none of these shapes

\footnotetext{
${ }^{84}$ Zarnkow et al. 2011.

${ }^{85}$ See Mallowan 1946, 150; Pfälzner 2007, 243.

${ }^{86}$ Valtz 2002-2003.

${ }^{87}$ Boehmer and Dämmer 1985, 12-17, 46-53, 83-4, pls. $28-$ $57,105-44,166-67$.
}

would look out of place at contemporary urban centers in the Mesopotamian heartland, such as Nippur, ${ }^{88}$ Isin, ${ }^{89}$ Ur, ${ }^{90}$ and Uruk. ${ }^{91}$ Nevertheless, it should be noted that, despite this typicality, there is more variation among individual shape types at Khani Masi ${ }^{92}$ than is often observed in Kassite assemblages, which are conventionally presented as highly standardized..$^{93}$ Work is currently ongoing to determine whether some of this variation is chronologically determined and thus has the potential to provide significant information on settlement development in the Diyala region. Alternatively, this variation may be of a technological nature, relating to the complexities of forming technique and the skill levels of the potters involved. The latter would have cultural connotations, relating to the organization of potting networks and their associated communities of craft practice.

The cause of the destruction that sealed the drinking assemblage in Y88 is difficult to determine. With no signs of burning or evidence of violence, seismic activity offers the most plausible explanation. The Zagros Mountains, a structural element of the Alpine-Himalayan belt, is one of the most seismically active fold-and-thrust belts in the world, with more

\footnotetext{
${ }^{88}$ Armstrong 1993.

${ }^{89}$ Kaniuth 2017.

${ }^{90}$ Woolley 1965, 97-100, pls. 38-46.

${ }^{91}$ van Ess 2014, 335-36, pls. 1-4.

${ }^{92}$ Also Glatz and Casana 2016, 141-43.

${ }^{93}$ Armstrong 2017.
} 


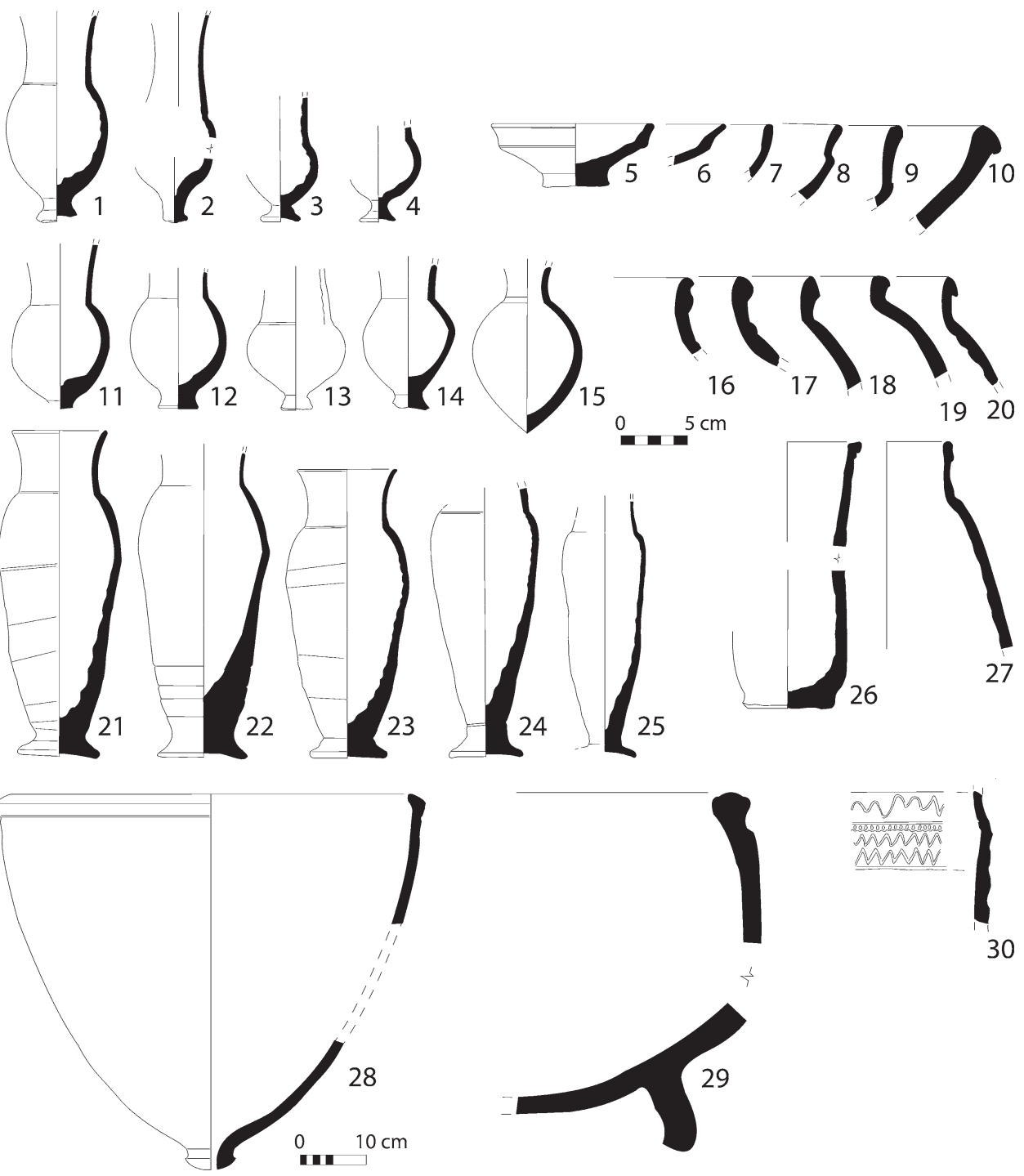

FIG. 9. Late Bronze Age pottery assemblage from phases 1-3 of SRP 46: 1-4, 13, 14, pedestal cups; 5-10, bowls; 11-12, flat base cups; 15, bottle; 16-20, 27, jars; 21-5, goblets; 26,30 , cylindrical vessels; 28 , vat with perforated base; 29 , large jar with applied ring base.

than 200 earthquakes recorded in the last half century alone. ${ }^{94}$ The epicenters of one major earthquake (7.5 on the Richter scale) in November 2017, which caused large-scale loss of life and structural damage, and a less powerful second quake in February 2018, for instance, were located only a few kilometers from Khani Masi. Archaeological evidence of seismic activity in the wider region comes from Godin Tepe level III, the destruction of which has been interpreted as the result of an earthquake ca. $1650-1600$ B.C.E.; the

\footnotetext{
${ }^{94}$ Nissen et al. 2011, 928, 936.
}

site appears to have been abandoned thereafter. ${ }^{95}$ At Khani Masi, too, the structure in Y 88 was not rebuilt following this destruction event sometime in the 14th century B.C.E. The massive walls of the structure, however, would have continued to be visible, as the building was left to disintegrate in the midst of Khani Masi's urban core. Two cult-related depositions and an infant jar burial dug into Room 1 along Wall 1, which all belong to phase 3 , suggest the building's continued significance as a place of ritual and memory.

\footnotetext{
${ }^{95}$ Young 1969; Young and Levine 1974, $25-6$.
} 
A Second Unbaked Mudbrick Structure (Trench V85). The magnetic gradiometer survey indicated the presence of another large (about $30 \times 40 \mathrm{~m}$ ) trapezoidal structure to the northwest of $Y 88$, consisting again of a large courtyard with a series of rooms along its western side. Several large magnetic anomalies also dot the plan of the structure (see fig. $5[\mathrm{C}]$ ). Excavations in trench V85 (see fig. 6) over a $10 \times 10 \mathrm{~m}$ area, however, revealed a somewhat more complex architectural picture and phasing of activities (fig. 10).

The first phase of activity in V85 was indeed the construction of a sizable unbaked mudbrick building, roughly contemporary with the structure in Y88. Wall 1 , which runs from the center of the southern section all the way into the northern portion of the west section, and Walls 2 and 3 formed part of this first architectural feature. A small sounding (about $2.3 \times 0.6$ $\mathrm{m}$ ) to the east of Wall 1 and south of Wall 2 revealed a floor abutting Wall 2 and an earlier phase of Wall 1 that had been cut by a pit burial (see fig. 10, Burial 1; fig. 11, left). The skeleton of a child was flexed and laid on its right side, facing north. A solid-footed goblet rested against the face of the deceased, who was buried wearing two striking multicolored beaded necklaces, one with larger beads consisting of different types of marble, glass, and rock crystal, carnelian from the Caucasus or India, and a shell (Engina mendicaria) from the Persian Gulf or the Red Sea and a second necklace with very small, short, tubular, multitoned cream, blue, and pinkish faience beads. These bead types are all known from the third millennium B.C.E. onward and are considered typical for Bronze Age burials in terms of both material and form. ${ }^{96}$ It has been suggested that such ornaments were given to children to protect them from illness or the evil eye as part of more complex rituals. ${ }^{97}$

A charcoal sample from a deposit sealing the burial and below the floor between Wall 1 and Wall 2 dates the subfloor inhumation to between cal B.C.E. 1505 and $1416(2 \sigma)$ (see table 1 ) and provides a broad terminus ante quem for the construction of the first phase of this structure. The architectural features exposed in the southern half of the trench (Walls 4-6) and the two large kilns (Kilns 1-2) overlying the earlier structure formed part of a later phase of activity (phase 2), a widespread reinterpretation of urban space into areas

\footnotetext{
${ }^{96}$ Wygnańska and Bar-Yosef Mayer 2018, 286.

${ }^{97}$ Dunham 1993, 240.
}

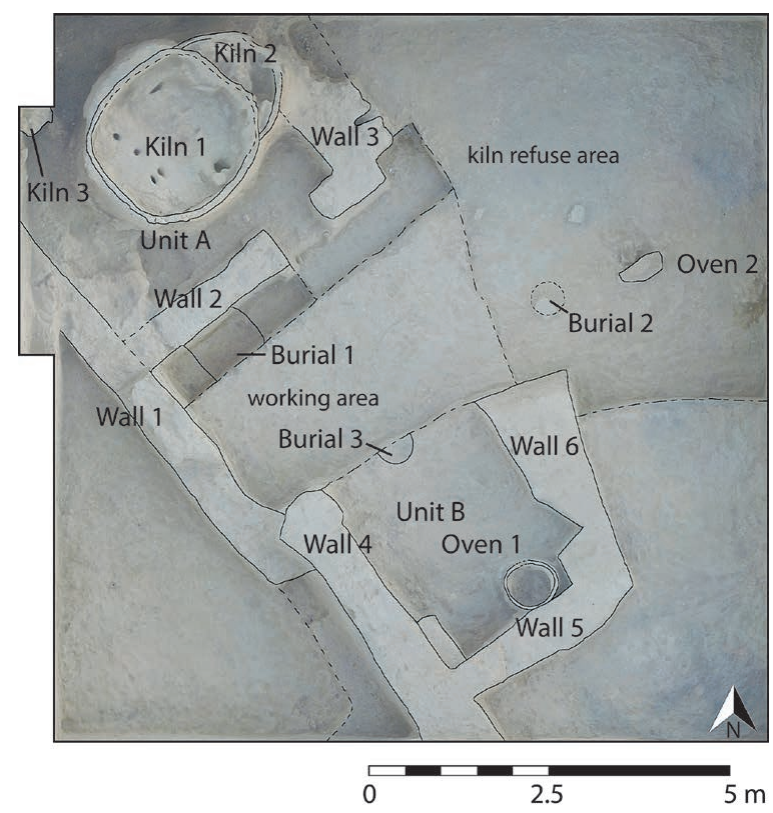

FIG. 10. Annotated orthoimage of trench V85 showing architectural remains from phase 1 (Walls 1, 2, and 3, Burial 1) and an industrial complex belonging to phase 2 (Kilns 1 and 2, Ovens 1 and 2, refuse area, Burial 2, Walls 4-6).

of industrial production that can be traced across much of the northern portion of the site.

\section{Phase 2: Industrial Reinterpretation}

Trench V85. The first sign of this industrial reinterpretation in V85 would appear to be the small, domed Oven 2 to the east of the first architectural complex, although Oven 2 may also have been partially contemporary with the last incarnation of the earlier structure. Once the earlier structure had gone out of use (there are no signs of a violent destruction), the room enclosed by Walls 1, 2, and 3 was filled with fine sandy soil to provide a flat surface for the construction of the first of two large, domed updraft kilns (Kiln 2 is older and was cut into by Kiln 1, see below), whose ashy refuse was deposited in the northeast quadrant of the trench (fig. 12). A third kiln or oven, Kiln 3, the bulk of which remains in the west section of V85, lies slightly to the west of Kiln 1 on top of Wall 1. Strewn in and around the two kilns were numerous fragments of greenish, overfired pottery and occasional kiln wasters.

The earlier Kiln 2 was cut into and largely removed to make way for the later and somewhat larger Kiln 1. Preserved of the latter is an internal platform with 13 irregular holes, where the pottery to be fired would have been stacked. A stoking chamber was accessed 

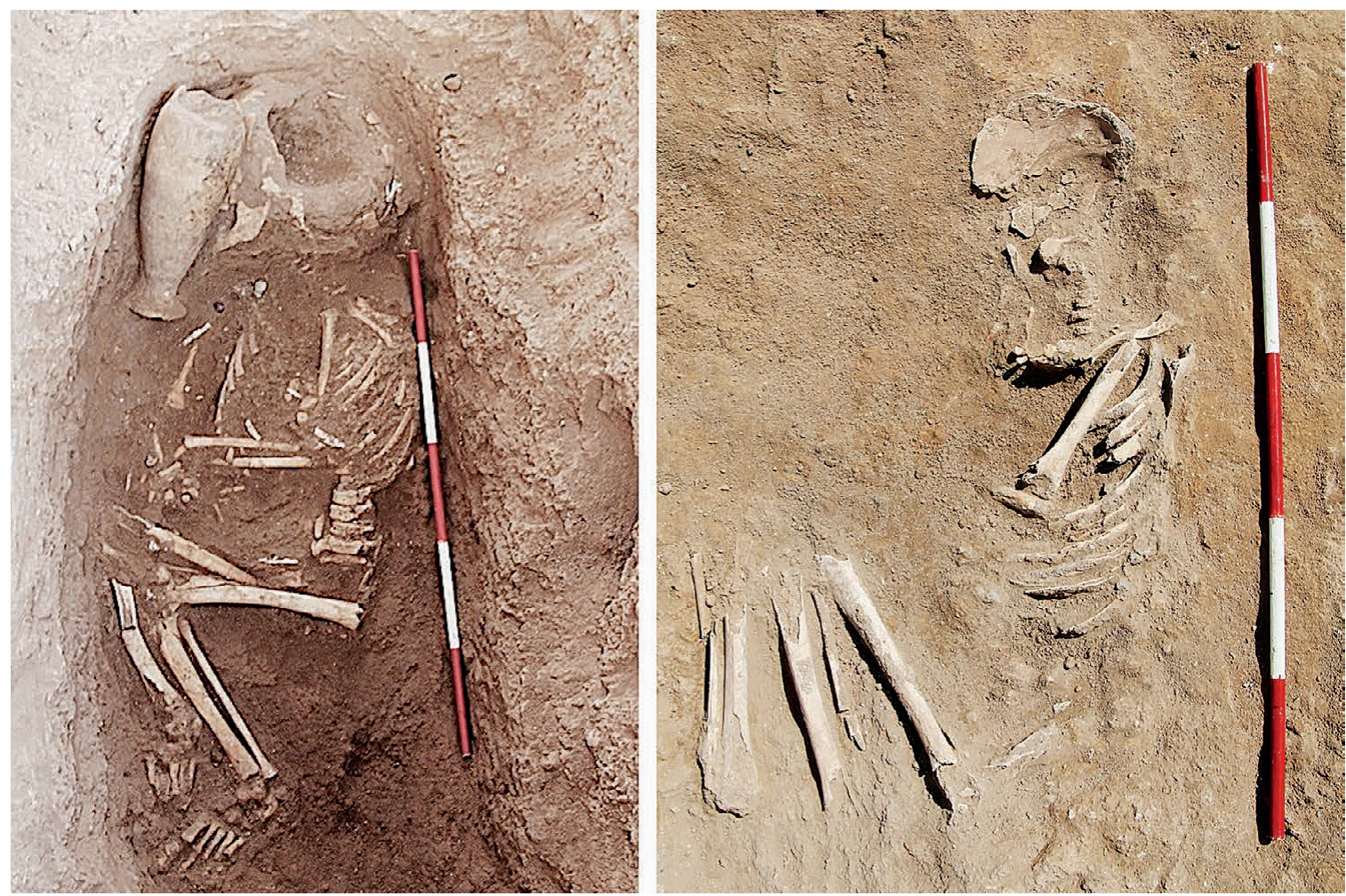

FIG. 11. Burial practices at SRP 46: left, subfloor inhumation, Burial 1, phase 1 in trench V85; right, inhumation in ashy rubbish dump, Burial 2, phase 2 in trench V85.

at the back of the kiln to the west, while a small mudbrick structure to the southwest contained a hearth or charcoal pit possibly to prepare fuel for the stoking chamber.

Tell Kesaran ${ }^{98}$ and Tell Zubeidi each yielded Late Bronze Age pottery production sites. Of these, two oval kilns (Gewölbeöfen) at Tell Zubeidi99 share characteristic building methods with Kiln 2. In these kilns, mudbrick columns on the long sides are built up to form the dome of the firing chamber, and the stoking chambers are located at the back. The two Zubeidi kilns, which the excavators date to the early to mid 12 th century B.C.E., were constructed in plaster- and brick-lined pits dug into the remains of the abandoned final Siedlung $\mathrm{I}^{100}$

The relationship between Kilns 1 and 2 and the suite of walls in the southern part of the trench has been rather challenging to establish. The bottom elevations of Kiln 1 and Walls 4 and 6 imply a roughly

\footnotetext{
${ }^{98}$ Valtz 1985, 69.

${ }^{99}$ Boehmer and Dämmer 1985, 31, pls. 66.1; 74.1, 2; 77.1, 2.

${ }^{100}$ Boehmer and Dämmer 1985, 32.
}

contemporary use of an open working area framed by mudbrick walls on three sides. A large round tannur (Oven 1) is located against Walls 5 and 6. Among the more unusual finds from this area is the deliberate burial of a large pig skull on the northern edge of the area enclosed by Walls 4-6. East of the kilns and the working area, in the northeast quadrant of the trench, was a large waste-disposal area built up of many small heaps of fine ash mixed with other waste and fuel removed from the kilns. Early during this buildup, an infant burial (see fig. 10, Burial 2; fig. 11, right) was placed in this area and subsequently covered by more ashy refuse. The deceased was flexed and placed on his or her right side facing north. Two small, seed-shaped beads and a small, fragmentary metal ring were associated with the skeleton. At a higher elevation than the pottery kilns, several small heaps of slag and metalliferous waste were encountered in the southeastern quadrant of the trench, suggesting a shift toward metalworking in the final stages of phase 2 .

Trench L80. Numerous additional magnetic anomalies scattered across the northwestern part of the site (see fig. 5[C, D] and to the west) were detected by the 


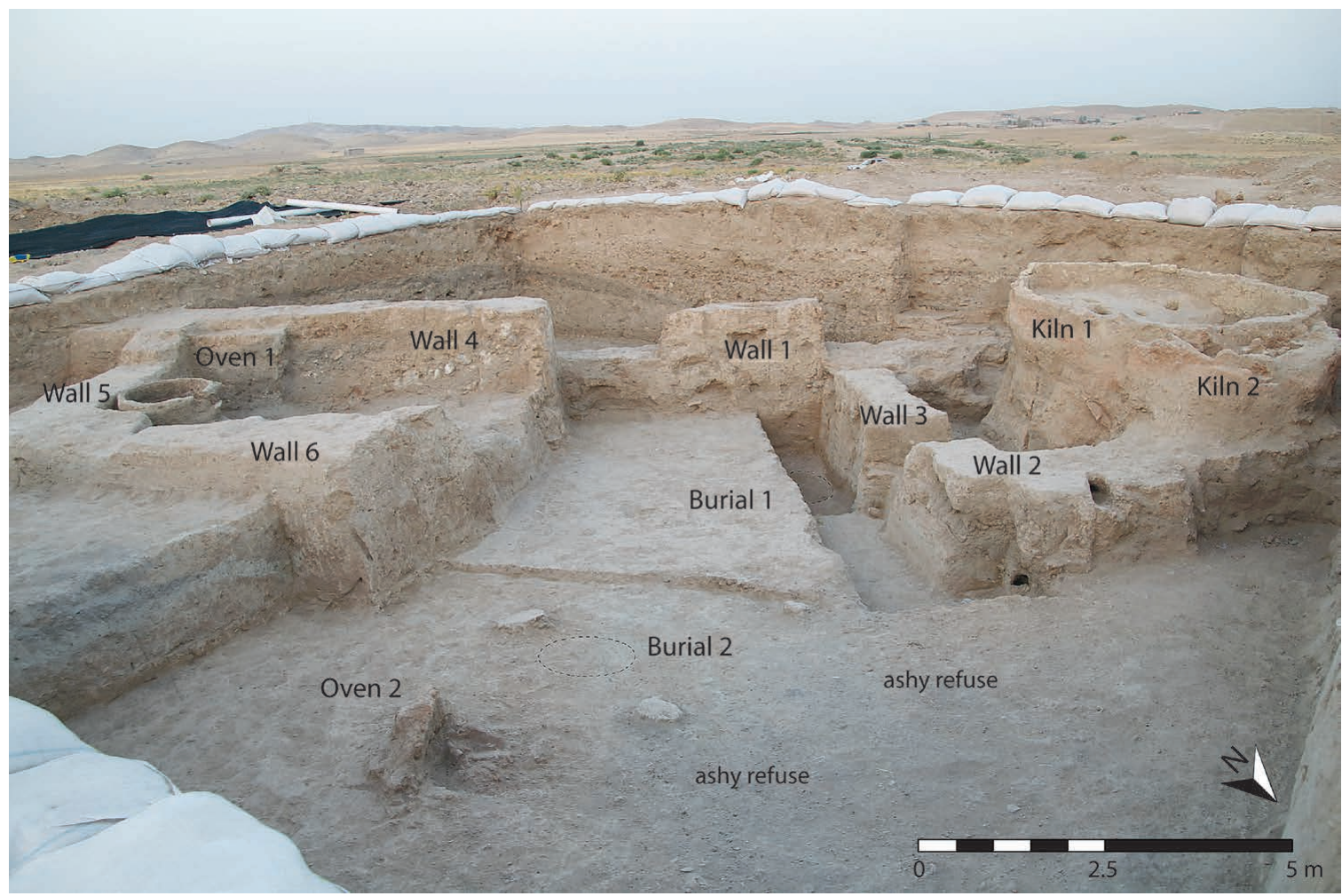

FIG. 12. View of trench V85, looking southwest. Architectural remains from phase 1 (Walls 1, 2, and 3, Burial 1) and an industrial complex belonging to phase 2 (Kilns 1 and 2, Ovens 1 and 2, refuse area, Burial 2, Walls 4-6).

magnetic gradiometer survey. These, along with the evidence from V85, may point toward the development of an extensive industrial zone, focused on pyrotechnological crafts, across the northwestern part of the site in phase 2 . In trench $L 80$, about $100 \mathrm{~m}$ northwest of V85 (see figs. 6, 13), we exposed another such industrial area consisting of a large kiln, two tannur ovens, and a food preparation area. Of the fire installations in L80, Kiln 1, which was sunk into the ground, was the most elaborately constructed. It is circular in shape and would originally have been hemispherical in profile. The internal structure of the kiln, although incompletely preserved, displays an elaborate network of chambers separated by a baked-clay framework that is comparable to one of the kiln structures at Tell Kesaran. ${ }^{101}$

Around the outside of the kiln, a series of depressions was sunk into the ground. In the southern depression, a well-preserved flue connects the inside of the kiln with the outside and was presumably used as

\footnotetext{
${ }^{101}$ Valtz 2002-2003, pl. 167, top left.
}

an access point for stoking the fire. In the western depression, a different type of opening is present that may have been used to control airflow into the kiln during firing. Two overfired ceramic wasters found in the kiln fill suggest that the function of Kiln 1 was firing pottery. The depressions around the kiln contained a large amount of ceramics, lithics, and bone and also yielded fragmentary metal pins or needles and one of bone.

The southern fire installation, Oven 1, appears to be somewhat later in date and, rather than being sunk into the ground, was constructed mostly aboveground with mud-plaster building material sloping down from near the top to meet or overlie the surrounding surfaces. It is circular in shape, and there appears to be an opening on the east side. The less elaborate nature and relatively small size of the interior space suggest, perhaps, a function as a bread oven. This interpretation would seem to be supported by the presence of cooking wares to the north of the installation. A stone grinder was found sitting on the floor surface directly west of Oven 1 .

In the southwest corner of the trench, a concentration of features again suggests an area used for food preparation. These include the partial opening of a 


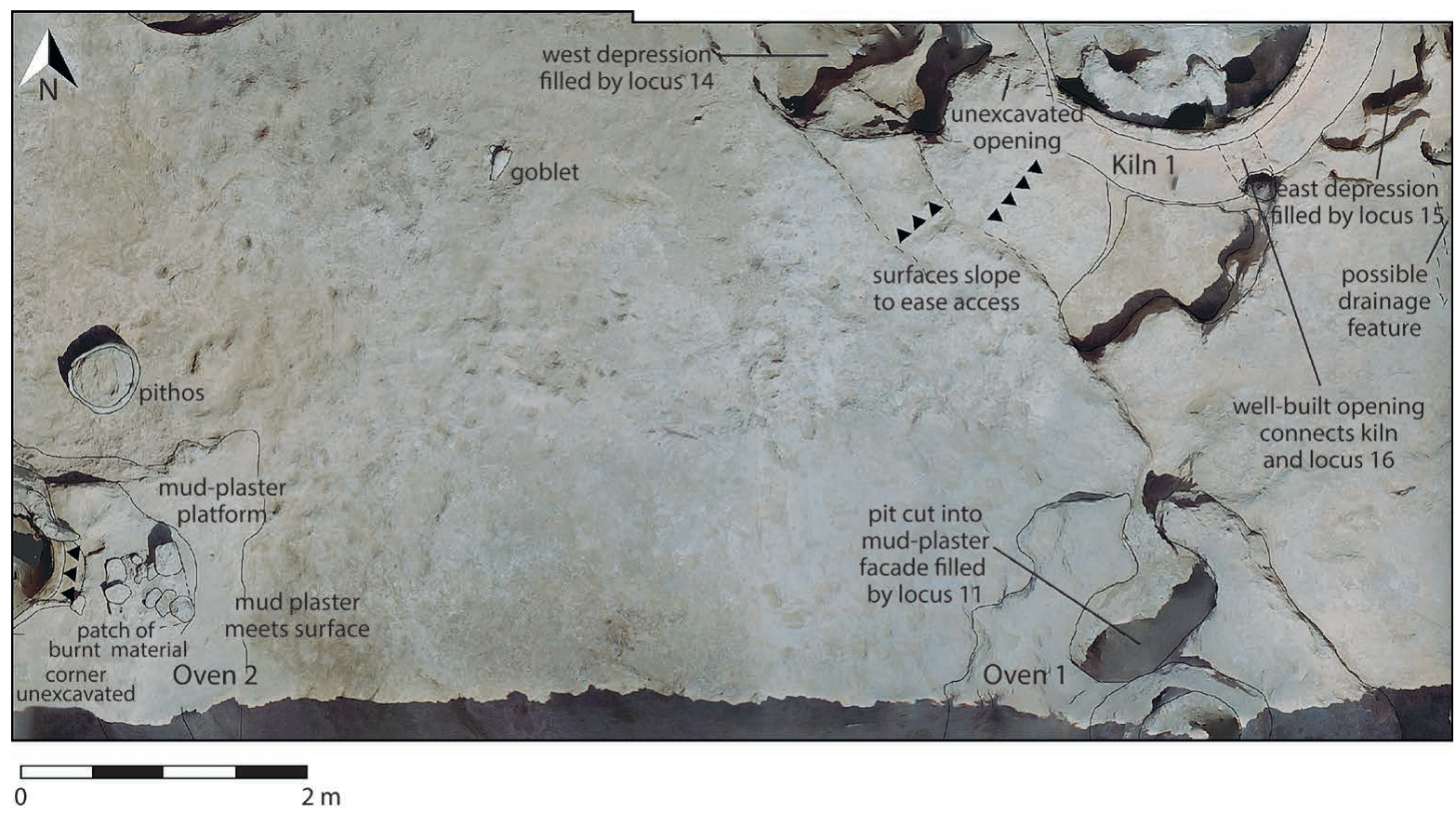

FIG. 13. Annotated orthoimage of phase 2 in trench L80 showing industrial installations (Kiln 1 and Oven 1) and cooking installations (Oven 2 and pithos) connected by a working surface.

baked-clay structure (see fig. 13, Oven 2) in the western trench section. This oven was built slightly above the surrounding surfaces, and a mud-plaster platform slopes from the surrounding surfaces up against its eastern and southern sides, creating a platform just east of the oven's opening. On this platform sits a roughly square arrangement of baked bricks with a loose ashy deposit among the bricks. Directly to the north of these features was a complete pithos set into the surrounding surface (see fig. 9, no. 29). The formal characteristics of this storage vessel, which has a large, open mouth, globular body, and large ring base, suggest a date in the later 13 th and early 12 th centuries B.C.E. ${ }^{102}$ A complete footed goblet as well as several concentrations of bone, including an intact human jaw and a separate collection of teeth, were found farther to the northeast on the walking surface connecting the different activity areas in the trench. A large quern stone was found in a higher deposit, about $20 \mathrm{~cm}$ above the working surface, but it was most likely associated with the general function of the area. Very similar arrangements of fireplaces or tannurs and associated pithoi set

${ }^{102}$ Armstrong and Gasche 2014, Type 260B. into the ground nearby are attested in the later settlement at Tell Zubeidi. ${ }^{103}$

\section{Archaeobotanical and Faunal Remains from Phases 1 and 2}

A preliminary assessment of the archaeobotanical and faunal records from contexts associated with phases 1 and 2 include the expected ranges and ratios of ancient Near Eastern domesticates. For the archaeobotanical record, this so far includes barley (Hordeum sativum), emmer (Triticum dicoccum), einkorn (Triticum monococcum), bread wheat (Triticum aestivum), and lentils (Lens culinaris). The faunal data suggest a predominance of sheep, with goat, pig, and cattle also represented. This is broadly in line with Late Bronze Age Mesopotamian sites such as Nippur, where a major dietary shift occurred between the Old Babylonian period and the Kassite period, when cattle, pig, and goat diminish significantly in favor of sheep. ${ }^{104}$ What is notable, however, from the Khani Masi faunal assemblage is the relatively high proportion of pig remains in comparison to the Late Bronze Age as-

\footnotetext{
${ }^{103}$ Boehmer and Dämmer 1985, 29-30, pl. 73.2.

${ }^{104}$ Boessneck 1993, 280-84; Boessneck and Kokabi 1993,
} 299. 
semblage at Nippur. Differences in local site environments may have played a role in the higher proportion of pigs at Khani Masi, ${ }^{105}$ but the greater frequency of pigs may also reflect social or cultural differences in consumption practices. Another notable feature of the Khani Masi faunal assemblage is the presence of gazelle bones. These animals may have been hunted for food during their seasonal migration up and down the $\mathrm{Za}$ gros through the Diyala valley. This small assemblage contrasts with that at Tell Asmar, ${ }^{106}$ where only horn cores have been identified, an indication that the horns were hunting trophies or ritual objects and that gazelles were not a source of food. The Khani Masi material includes both head and postcranial elements, evidence that gazelles were hunted for food, as they were at contemporary sites such as Isin in lowland Mesopotamia and Tepe Guran in the Iranian highlands. ${ }^{107}$

\section{Phase 3: Memories of Ruination}

A Deliberately Buried Ceramic Stand in Trench L80. The disuse of the industrial installations in both V85 and L80 is followed, as in the case of the monumental structure in Y88, by a phase of diverse ritual and funerary depositions. The most evocative of these ritual depositions was found in the center of the western half of trench L80. Above the surfaces connecting the earlier fire installations, Kiln 1 and Oven 1 (see fig. 13), was found a compact, dark brown deposit that contained two concentrations of baked bricks and overfired, greenish-blue brick fragments. Placed amid the eastern concentration and deliberately covered by the bricks and brick fragments was a large cylindrical ceramic object, most likely a stand with fenestrations at the top, that has a prominent decorative relief showing three hybrid creatures (Mischwesen, fig. 14). The object is, as far as we know, unique, although large ceramic cult stands are attested in other Late Bronze Age Babylonian ritual contexts, such as the Gula Temple at Isin. ${ }^{108}$ Morphology, iconography, and depositional context, including the deliberate covering of the relief by overfired bricks, point quite unambiguously not only to a ritual function of the object itself but also to a deliber-

\footnotetext{
${ }^{105}$ Grigson 2007.

${ }^{106}$ Hilzheimer 1941, 22-3.

${ }^{107}$ Clutton-Brock 2001.

${ }^{108}$ Haussperger et al. 1981, 9, pl. 2.1, fig. 1.
}

ate act of deposition that may have marked the closure or commemoration of the industrial complex. The symbolism of the stand's relief decoration is intriguing in its own right, as it appears to reference the complex psychology of Mesopotamia's relationship with the Zagros Mountains.

The central figure on the decorative frieze is a scorpion man with bird's legs and body, the upturned tail of a scorpion, and a bearded human face. He is flanked on either side by two winged creatures that can be identified either as lion-dragons or snake-dragons. In Mesopotamia, scorpion people (aqrabuamelu or girtablullu) are first attested in the Early Dynastic III period (ca. 2900-2350 B.C.E.). A scorpion man is depicted, for instance, on one of the plaques covering the sound box of the lyre with the blue-bearded bull's head from the Royal Cemetery of Ur. ${ }^{109}$ Scorpion people were created by Tiamat, the primordial goddess in the Babylonian epic of creation, the Enūma Eliš. ${ }^{110}$ In the Gilgameš epic, scorpion-human hybrids guard the gate to the netherworld at the twin mountains of Mašu, where the sun passes through as it sets and rises. ${ }^{11}$ Scorpions are depicted frequently on Babylonian kudurru stones, such as the donation of Meli-Šipak to his son Marduk-apla-iddina I. ${ }^{12}$ A scorpion Mischwesen with human face, the body and legs of a bird, and a scorpion tail is depicted on the kudurru of Nabu-kudurri-usur I (1126-1103 B.C.E.). ${ }^{113}$

The two creatures flanking the scorpion man at Khani Masi defy ready identification because of the rudimentary rendering of features, on the one hand, and what appears to be an element of deliberate blending or ambiguity, on the other. They share some characteristics of lion-dragons, including lion forelegs and bushy lion tails. Lion-dragons are generally depicted with wings from the Akkadian to the Neo-Babylonian period. ${ }^{114}$ They may be equated with the Asag or, more likely, with the Imdugud/Anzu. The Asag is a monster in Mesopotamian mythology who mates with Kur, the mountain, and is accompanied by an army

\footnotetext{
${ }^{109}$ Tomb PG/789, P1. 105, U. 10556, Woolley 1934, 280.

${ }^{110}$ Dalley 1989, 237; Talon 2005; Lambert 2018.

${ }^{111}$ Dalley 1989, 96-7; George 2003, 71.

${ }^{112}$ Supra n. 40.

${ }^{113}$ Seidl 1989, no. 67.

${ }^{114}$ Black and Green 1992, 121.
} 

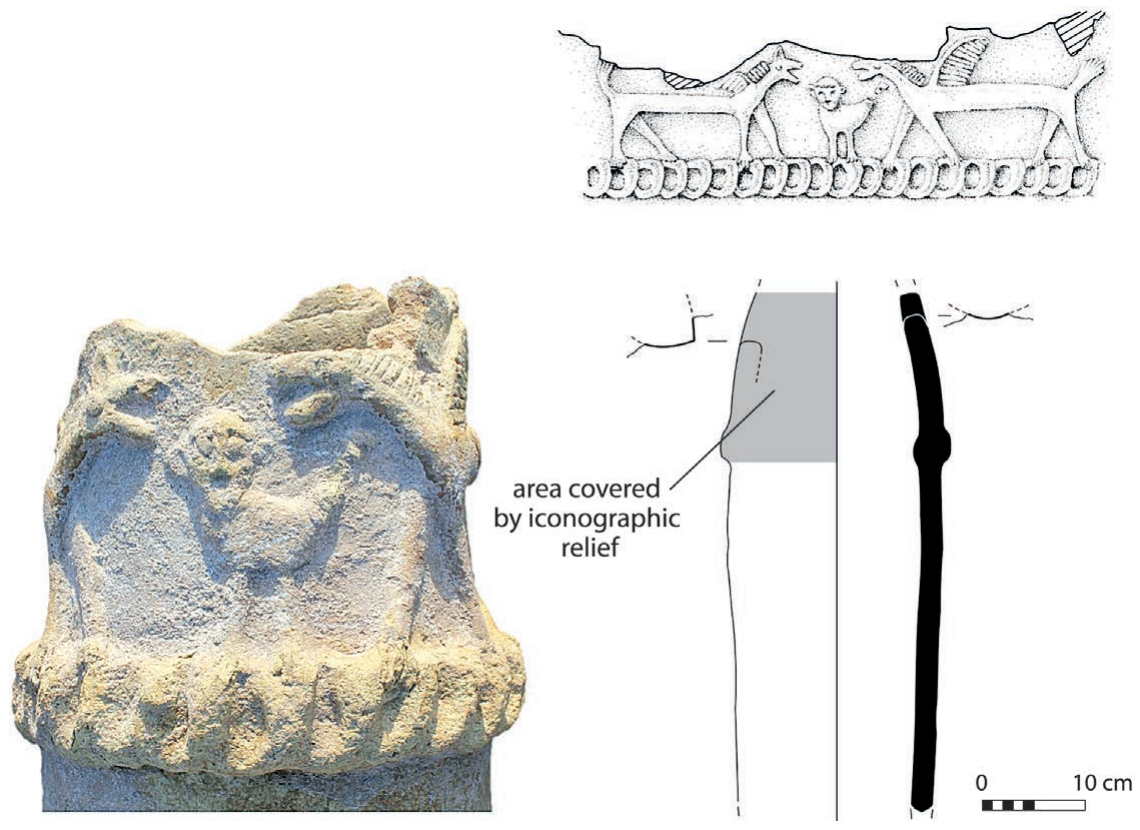

FIG. 14. Ceramic object with relief decoration, deposited during phase 3 in trench L80. The deposit marked the closure of the industrial complex in the eastern part of the trench.

of stone allies. ${ }^{115}$ The Anzu is a lion-headed eagle that steals the tablet of destinies from the god Enlil. ${ }^{116}$ In the Lugalbanda poem, the hero wanders the Zagros Mountains and comes upon the Anzu fledgling in its nest. ${ }^{117}$ Such lion-dragons appear frequently on Babylonian kudurrus, where they represent an aspect of the war god Ninurta, who in Sumerian myths defeats the mountainous lands to the east of Mesopotamia as well as both the Asag and the Anzu. ${ }^{118}$ A lion-dragon with wings and a pointed ear or horn similar to those on the Khani Masi stand is depicted on the reverse of

\footnotetext{
${ }^{115}$ For the Lugale text: van Dijk 1983; "Ninurta's Exploits: A Šir-sud (?) to Ninurta” (2003), Black et al. 2006, http:// etcsl.orinst.ox.ac.uk/cgi-bin/etcsl.cgi?text=t.1.6.2\#. Black and Green (1992, 36, 142, fig. 117) suggest that the Asag's defeat by Ninurta may be depicted on one of the relief orthostats commissioned by the Neo-Assyrian king Assurnasirpal II (883-859 B.C.E.) for his palace at Kalhu (Nimrud) (London, British Museum, inv. no. 124571).

${ }^{116}$ For a translation of the Anzu story: Dalley 1989, 203-28; Annus 2001; Foster 2005.

117 “Lugalbanda and the Anzu Bird” (2003): Black et al. 2006, http://etcsl.orinst.ox.ac.uk/cgi-bin/etcsl.cgi?text=t.1.8.2.2\#.

${ }^{118}$ Black and Green 1992, 142-43. "Ninurta and the Turtle": Alster 1972; van Dijk 1983; Black et al. 2006 (1998), http:// etcsl.orinst.ox.ac.uk/section1/tr163.htm. "Ninurta's Exploits: A Šir-sud (?) to Ninurta”: Black et al. 2006 (2003), http://etcsl. orinst.ox.ac.uk/cgi-bin/etcsl.cgi?text=t.1.6.2\#.
}

the kudurru of Marduk-apla-iddina I, which was found near Sarpol-e Zohab. ${ }^{119}$

Snake-dragons, or mušhuššu, by contrast, tend to be depicted with horns, a snake's body and neck, a lion's forelegs, and a bird's hind legs. ${ }^{120}$ The two creatures depicted on the Khani Masi ceramic object do not have scales, but their elongated bodies resonate more with the depictions of snakes in Mesopotamian iconography than of lion-dragons. It is also unclear whether the Khani Masi dragons are depicted with lion ears or mušhuššu horns. Lion-dragons with some characteristics of snake-dragons are frequently depicted on Babylonian relief carvings in association with, or standing in for, the god Marduk. ${ }^{121}$ Marduk rose from a relatively obscure position in the Mesopotamian pantheon to become a great god during the Old Babylonian period, when Hammurabi made Babylon his political center, and to become the chief deity in the course of the Late Kassite period. ${ }^{122}$ Snake-dragons are depicted either partially, such as on a fragmentary relief carving from Susa where mušhuššu heads decorate Marduk’s ship,

\footnotetext{
${ }^{119}$ Supra n. 40.

${ }^{120}$ Black and Green 1992, 166; Wiggerman 1995.

${ }^{121}$ E.g., Seidl 2017, 320, fig. 12.13.

122 Sommerfeld 1982; Lambert 1984, 1; Tenney 2016; Nielsen 2018, 165-66.
} 
or seated with lion's feet and tail, with bird's feet, or in the form of a snake. ${ }^{123}$

Ritual Depositions in Trench Y88. Evidence for ritual closures and memorializations is found in other parts of Khani Masi, including in the monumental structure in Y88 (see fig. 7). Dug into the final collapse layer of the central Room 1 were at least three separate instances of ritual depositions. One was a neonatal or small infant jar burial dug along the northern wall of Room 1. The other two, not directly associated with burials, appear to be ritual offerings consisting of two ceramic vessels and a so-called faience bucket. Offering 1 (fig. 15a), which was placed on top of or dug into the final collapse layer in the central part of Room 1, consisted of two very similar drinking goblets with globular bodies, flaring rims, and narrow bases, ${ }^{124}$ a faience bucket with loop handles, ${ }^{125}$ and a gold earring. Also found nearby was the better part of a beer-brewing vat, a large open-mouthed vessel with a perforated base

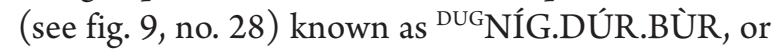
namzitu in cuneiform sources. ${ }^{126}$ Offering 2 (see fig. $15 \mathrm{~b}$ ) was dug into the western wall of Room 1 and consisted of a simple straight-sided bowl in which were stacked a drinking goblet with a straight neck ${ }^{127}$ and a faience bucket with a simple rim. ${ }^{128} \mathrm{~A}$ small fragment of a faience bucket was also found wedged into the side of Kiln 2 in V85.

Faience buckets are small pyxides made of glazed frit, a highly friable vitreous material that is generally associated with Late Kassite burials at both the major urban centers of Babylonia and the more modest estates and villages of the Hamrin such as Tell Zubeidi and Tell Imlihiye. Individual faience buckets have been found as far afield as Susa, Mari, Emar, Ugarit, Megiddo, and Enkomi. ${ }^{129} \mathrm{~A}$ Babylonian origin for these vessels is generally assumed, ${ }^{130}$ but their increasing prominence along the Diyala equally could point to a local tradition.

\footnotetext{
${ }^{123}$ Seidl 2017, 319, fig. 12.12 .

${ }^{124}$ For comparisons, see Armstrong and Gasche 2014, Group 195.

${ }^{125}$ For comparisons, see Clayden 1998, Type II.

${ }^{126}$ Gates 1988, 66-8.

${ }^{127}$ For comparisons, see Armstrong and Gasche 2014, Group 205.

${ }^{128}$ For comparisons, see Clayden 1998, Type I.

${ }^{129}$ Clayden 1998, 50.

${ }^{130}$ Moorey 1994, 178-79; Clayden 1998.
}

Jar burials are also attested in the industrial zone of V85 following its abandonment in what appears to have been a midden area in DD89 in the far south of the site (see fig. 6) and in trench Z90 just to the southeast of the monumental complex in Y88 (see fig. 6). The use of abandoned or ruined structures as graveyards and the types of burial practices attested at Khani Masi find close parallels across Mesopotamia and at the Hamrin sites. In both areas, we find a diversity of burial practices ranging from subfloor inhumations, usually flexed and often with pottery and jewelry as grave goods, to single- and double-jar burials. ${ }^{131}$ The Khani Masi burial record, so far, consists of infants and juveniles, which compares well with Tell Zubeidi and Tell Imlihiye, where they also predominate. ${ }^{132} \mathrm{~A}$ jar with a bowl wedged into its cutaway mouth in Z90 is rare but can be compared to Grab 60 at Tell Zubeidi, ${ }^{133}$ which was dug into a wall following the abandonment of Siedlung I.

\section{Phase 4: Baked Brick Revival}

The ritual and burial depositions of phase 3, which represent the continued significance of the ruins of the monumental structure in Y88 and the two industrial areas (V85 and L80) to Khani Masi's inhabitants, indicate demographic continuity. This conclusion is further supported by the placement and identical northwest-southeast orientation of the buildings in the next phase of major architecture at the site, phase 4.

One of the reasons we selected Khani Masi for further analysis was the proliferation of baked bricks on the site's surface, which, together with the areas of high magnetism particularly in the southern portion of the mound, suggested the presence of substantial bakedbrick structures whose uppermost courses were being destroyed and brought to the surface by mechanical plows. Toward the end of the 2017 season, we partially exposed two of these baked-brick structures. Trench Z86 (see figs. 6, 16) exposed, over a $75 \mathrm{~m}^{2}$ area, the central portion of a square, multiroom building (about $20 \times 20 \mathrm{~m}$ in size), which is clearly visible on the magnetic gradiometer image (see fig. $5[\mathrm{~B}]$ ) and which is located less than $5 \mathrm{~m}$ to the southwest of the earlier monumental structure in Y88. A second, less well

\footnotetext{
${ }^{131}$ Sternitzke 2017, 359-62.

${ }^{132}$ Boehmer and Dämmer 1985, 5-7.

${ }^{133}$ Boehmer and Dämmer 1985, 45, pl. 95.4 .
} 

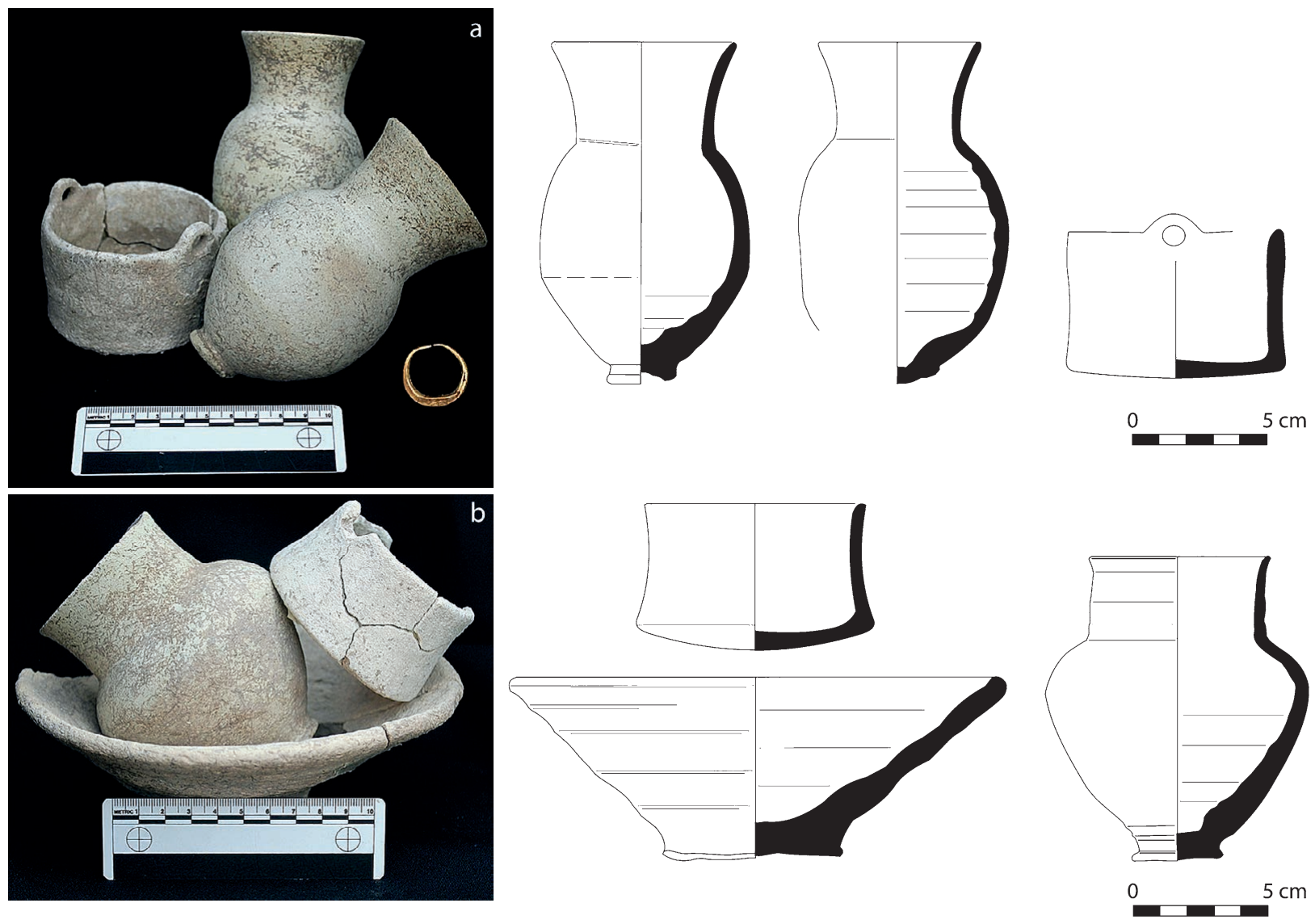

FIG. 15. Two offering assemblages that were dug into the ruined unbaked mudbrick structure in trench Y88 during phase 3: $a$, Offering 1: two drinking goblets, a faience bucket, and a gold earring; $b$, Offering 2: bowl, drinking goblet, and faience bucket.

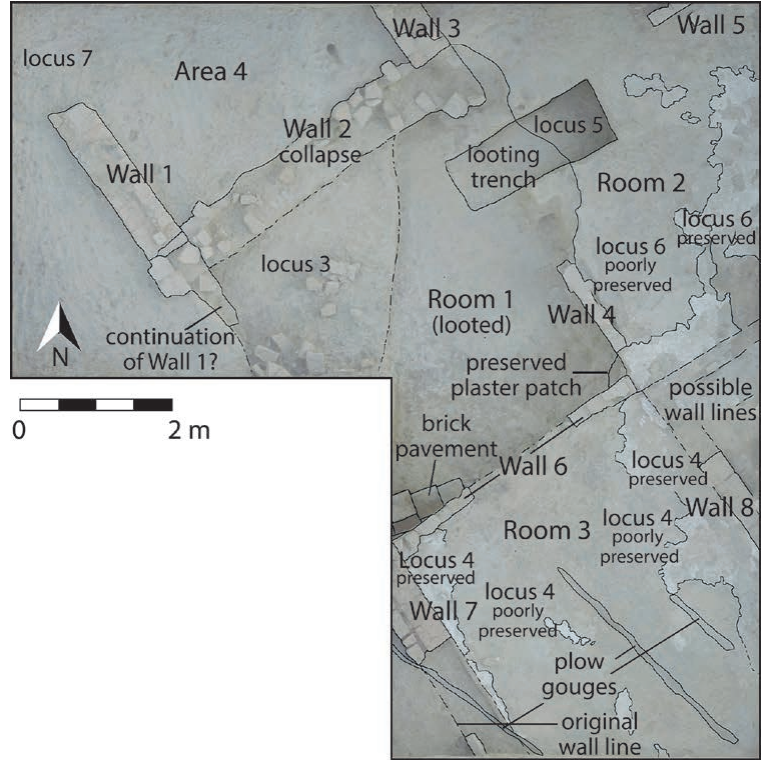

FIG. 16. Annotated orthoimage of phase 4 in trench Z86 showing part of a rectangular structure built from baked mudbricks, a partially preserved baked-brick pavement in Room 1 , and patches of well-preserved plaster floors in Rooms 2 and 3. preserved structure was partially exposed in Y96 (see fig. 6) along the southeastern edge of the site.

We uncovered three rooms and a possible external space in trench Z86 (see fig. 16). Despite ongoing damage by plow action and a recent and extensive episode of looting, the architecture is generally very well preserved and includes several courses of standardized baked bricks about $35 \times 35 \mathrm{~cm}$ in size and several layers of lime plaster on both floors and walls.

Room 1, in the center of the excavated portion of the building, was paved with baked bricks, two and a half rows of which survive in situ in the southwest corner (fig. 17), and was enclosed by different wall formats. Walls 1, 7, and 3 along the outside of the excavated rooms measured one and a half baked bricks, or about $55 \mathrm{~cm}$, in width, each course switching the side on which the full bricks and half bricks were placed. A second, interior wall is only one brick in width (Wall 8), and a third (Wall 6) uses only half bricks.

Room 1 was flanked by a possible outdoor area (Area 4) to the north. Rooms 2 and 3, to the northeast 


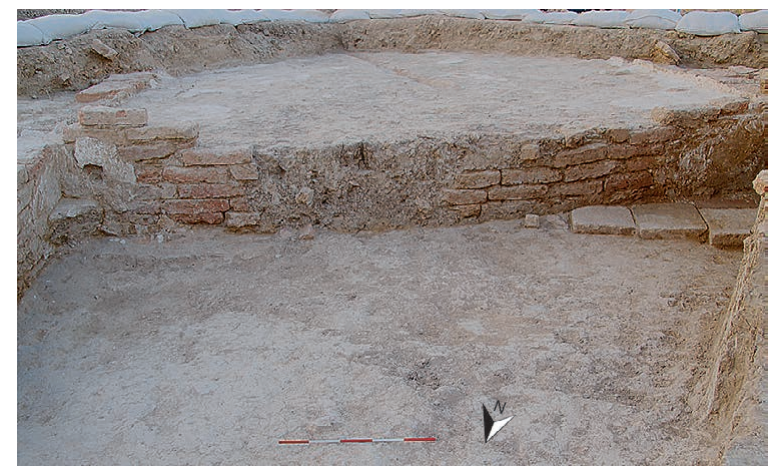

FIG. 17. View of Room 1 looking southeast, from phase 4 in trench Z86. Baked-brick pavement and Walls 4 and 6.

and south, had floors that were elevated by at least five brick courses above the pavement of Room 1. Several layers of white plaster facing run unbroken from the top of Wall 6 to the very bottom of the wall, where they meet and partially overlie the pavement in Room 1. A gap in the center of Wall 6 may have been an entrance to Room 3 in an earlier building phase. It is also possible that the small corner of plaster sitting partway between these two levels in the corner where Wall 4 and 6 meet represents the remains of a step down from Room 3 into Room 1.

Room 3, which measured about $3.75 \mathrm{~m}$ in width and at least $4.75 \mathrm{~m}$ in length, also revealed a plastered floor that meets the faces of the enclosing Walls 7 and 8 , even where bricks had been removed (fig. 18). The association between the plaster floor and Wall 6 illustrates a sequence of small-scale architectural modifications. Here, two phases of the plaster surface lie both over and under the line of the wall's top surviving course of bricks. It appears that the earlier phase of floor surface was laid over the top of Wall 6 , thus opening a large space joining Rooms 1 and 3. It was only later that the upper bricks were added to separate the two rooms. The second phase of plaster flooring was then laid up against the added wall bricks on either side.

Room 2 to the northeast is also dominated by a lime-plaster floor surface that is extremely well preserved in patches, particularly in the east of the exposure. In some areas, the plaster is up to $2 \mathrm{~cm}$ thick and clearly represents repeated episodes of surfacing. Where preserved, it covers the bottom edge of the southeast face of Wall 5. The plaster floor and Wall 5 must, therefore, have been contemporary, and the wall may originally have been faced with lime plaster.

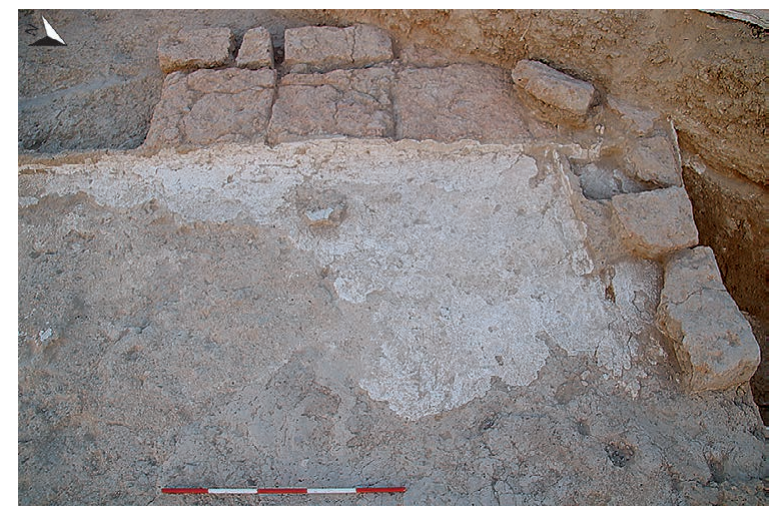

FIG. 18. View of plastered floor surface in Room 3 and Wall 7 from phase 4 in trench Z86, looking southwest.

Trench Y96 also exposed a large, multiroom rectangular structure that formed part of a series of aligned buildings protecting the southern perimeter of the site (fig. 19). Only the bottom course of baked bricks of two walls, however, was encountered here immediately below the topsoil; the rest had been removed by recent plowing, probably in 2016. Set on leveled and compacted soil, the preserved course of the wall is one and a half bricks wide, the same as Walls 1,3 , and 7 in Z86. The similarity of construction could suggest a similar date. With the exception of a small bronze pin with curled tip, no other material was associated with the walls.

It is as yet unclear how phase 4 came to an end. A burnt collapse layer, found associated with the brick course in Y96, could suggest a violent ending of some form, but the better-preserved structure in $\mathrm{Z} 86$ has to date yielded no indicators of how it may have met its end. The absence of artifacts on any of the floors, while perhaps a result of their close proximity to the plowed surface, may point to a deliberate clearing and closure.

Sparse finds also mean that the functions of the baked-brick structures remain difficult to define, although all recovered ceramic material and small finds can be dated with confidence to the late second millennium B.C.E. A charcoal sample from below one of the plaster floors in Z86, which was cut during a test excavation in 2014, provides a terminus post quem of cal B.C.E. $1258-1233(2 \sigma)$ for the start of phase $4 .{ }^{134}$ The

\footnotetext{
${ }^{134}$ Our original assessment of a limited second phase of occupation must now be revised in light of the substantial bakedbrick architecture in phase 4; Glatz and Casana 2016, 141, fig. 11.
} 


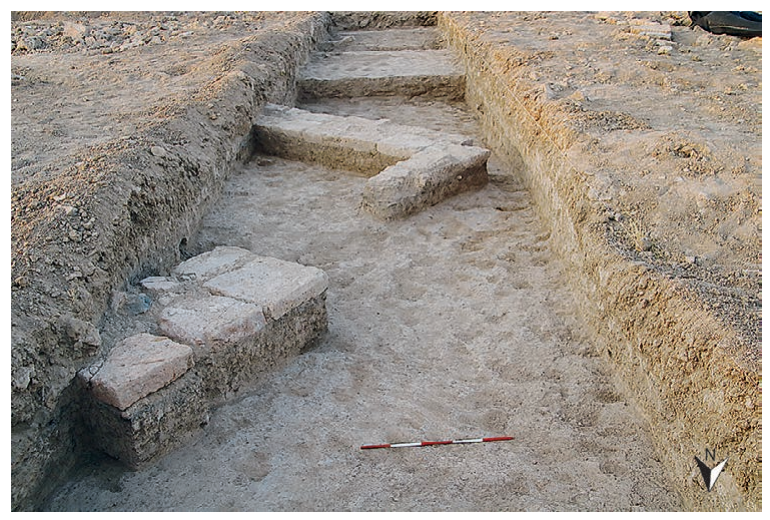

FIG. 19. Corner of a structure built with baked mudbricks from phase 4 in trench Y96, looking south.

extensive use of baked bricks, the logistics of their production, the size of the buildings, and their architectural layout seem to point to a public role and a central organizing authority to coordinate their construction. It is possible that some of the still unexcavated dipolar anomalies scattered across the site were kilns used to fire the thousands of mudbricks necessary for the construction of the many baked-brick buildings visible on the magnetic gradiometer image.

Baked bricks are used extensively, though not exclusively, in the construction and refurbishment of monumental temple and palatial architecture in Mesopotamia, as, for instance, at Ur. ${ }^{135}$ The so-called Gula Temple at Isin was rebuilt during the Late Bronze Age using primarily unbaked mudbricks, but baked bricks were used for the paved floors and a number of brick platforms that lined the entrances to the temple's Gula and Ninurta cellae. ${ }^{136}$ Overall brick sizes and the construction technique using only stretchers are attested at, for instance, Late Bronze Age Ur; however, the use of rubble packing between baked-brick wall faces found at Ur has not yet appeared at Khani Masi. ${ }^{137}$ Unlike many of the monumental structures in Mesopotamia, Khani Masi thus far has yielded no inscribed bricks. Inscribed bricks are also absent from Late Bronze Age sites in the Lower Diyala, ${ }^{138}$ and no baked-brick structures at all are attested in the Hamrin

\footnotetext{
${ }^{135}$ Woolley 1965, 3.

${ }^{136}$ Kaniuth 2017, 494-95, fig. 18.3.

${ }^{137}$ Woolley 1965, 3.

${ }^{138}$ Adams 1965, 53.
}

for this period, which was no doubt a function of the small-scale nature of the Middle Diyala settlements.

\section{Phase 5: Final Occupation with Reused Baked Bricks}

A final occupation phase, only centimeters below the topsoil, partly reused the baked bricks to produce small-scale structures and niches for tannur ovens. Two baked-brick features appeared to be graves but contained no preserved human remains. The finds associated with these structures, with the exception of a small number of glass bracelet fragments from the topsoil, do not contradict a late second-millennium B.C.E. date for this final activity phase, after which the mound was abandoned. Ephemeral pits and fireplaces suggest sporadic later use, perhaps as a campsite, by the nomadic tribes that roamed the region well into the 20th century C.E.

\section{A Late Third- to Early Second-Millennium B.C.E. Settlement}

In 2017, in order to explore the spatial extent as well as chronological range of occupation at the Khani Masi cluster, we opened a $5 \times 5 \mathrm{~m}$ test trench (K136) on the low mound of SRP 94 (see figs. 4, 5), the easternmost component of the site, following a geophysical survey in 2016. The results indicate the presence of a rather substantial late third- to early second-millennium B.C.E. settlement (fig. 20).

Excavations in K136 revealed two or possibly three structures, which are separated by a narrow northeast-southwest running alley. The mudbrick walls were constructed using three rows of bricks about 20 $\mathrm{x} 15-20 \mathrm{~cm}$ in size. Two building phases could be identified in the northern structure, where the removal of collapse fill revealed the room defined by Walls 3 and 5 in the earliest building phase (see fig. 20, locus 5). A charcoal sample provides a date between cal B.C.E. 2020 and $1880(2 \sigma)$ (see table 1) for the fill layers in the western room (see fig. 20, locus 6).

The alleyway in the east of the exposure is lined by Walls 1 and 2. These walls slump inward near their bases, where they meet the gray, undulating, trampled earth surface of the alleyway. In the southwest area of this alleyway, where Walls 1,2 , and 4 meet, a hard, green $1.1 \times 0.9 \mathrm{~m}$ platform was encountered. It is constructed of hard mud plaster and stands $25 \mathrm{~cm}$ above the surrounding street surface. Two individual drainage gullies (about $25 \times 25 \mathrm{~cm}$ in profile) run underneath Walls 1 and 2 to meet this platform. These 


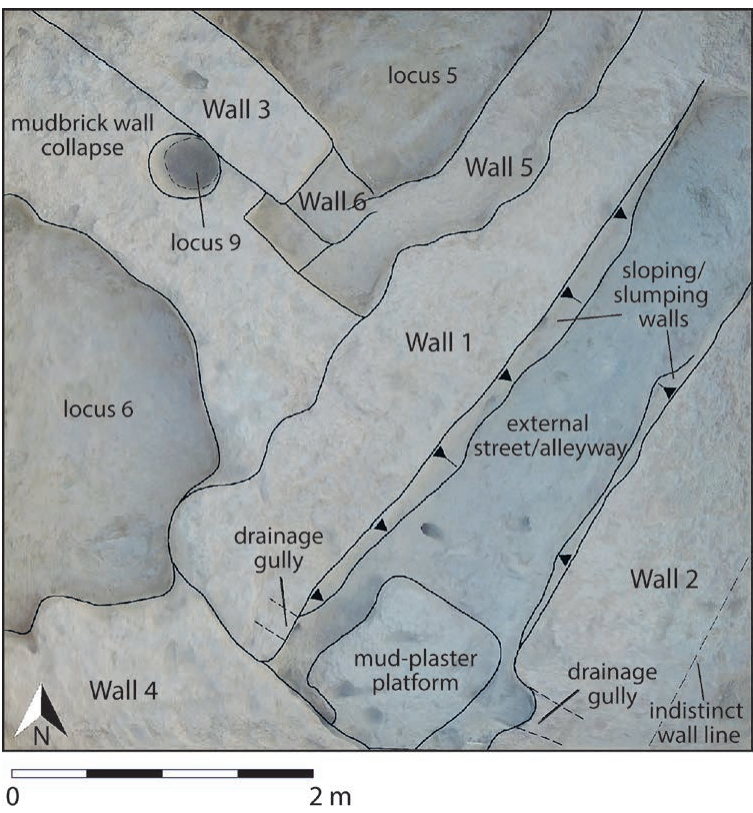

FIG. 20. A late third- to early second-millennium settlement on SRP 94. Annotated orthoimage of trench K136 showing two partially excavated unbaked mudbrick structures divided by an alleyway running northeast to southwest.

drainage features presumably operated to transfer water and waste from inside the surrounding buildings out into the alleyway.

Pottery finds confirm the early second-millennium B.C.E. date suggested by the charcoal sample. The vessel types include a large number of straight-sided or slightly concave beakers with flat or convex bases (fig. 21, nos. 5-8). ${ }^{139}$ These beakers are widely attested across central and northern Mesopotamia in the early part of the second millennium B.C.E., including in the neighboring Hamrin. ${ }^{140} \mathrm{~A}$ small beaker with a convex base and a painted band around the exterior rim finds a precise parallel in shape and decoration at the Hamrin site of Halawa. ${ }^{141}$

The pottery repertoire of K136 also includes a rather large proportion of medium to large storage jars with narrow necks and pronounced rims; the jars are decorated with applied bands, incised wavy lines, or pronounced parallel ribbing (see fig. 21, nos. 10-13). Similar types of vessels are known from the Early Dy-

\footnotetext{
${ }^{139}$ For comparisons, see Armstrong and Gasche 2014, Group 65.

${ }^{140}$ Yaseen 1995, pls. 112-331.

${ }^{141}$ Yaseen 1995, pl. 147, no. 564.
}

nastic Lower Diyala sites, ${ }^{142}$ but they are also typical of the early second-millennium B.C.E. levels at Nippur, for instance. ${ }^{143}$

A large ceramic tray with internal handles (fig. 22) represents a type that has a broad chronological and geographical distribution in the later third and early second millennia B.C.E., with significant concentrations along the Lower and Middle Diyala as well as into the upland areas of the Sharezor at Tell Bakr Awa and beyond. ${ }^{144}$ Bürger and Miglus believe that in the later Early Dynastic III and Akkad periods, these implements spread from southern Mesopotamia into the Lower Diyala and, during the Ur III period, into the Middle and Upper Diyala as well as into the northern Tigris area, while they decreased in popularity in the south. ${ }^{145}$ The function of these trays is as yet unknown, but a domestic use is most likely. ${ }^{146}$

Dug into the collapse layer of Walls 1 and 2 were found one nearly complete bronze bowl and a second fragment of a bowl bottom, which may perhaps point to a practice of ritual deposition similar to that attested for the Late Bronze Age on SRP 46. In coming seasons, we will explore whether there is a gap in occupation at Khani Masi during the intervening Old Babylonian period or whether settlement shifted from SRP 94 to one of the other low mounds that form part of the site cluster. Likely candidates for this include SRP 43 and SRP 44, which during surface survey yielded characteristic vessel forms for the Old Babylonian period, such as so-called button bases.

\section{DISCUSSION}

Our work at the Late Bronze Age site of Khani Masi and its regional settlement context provides us with an unprecedented new perspective on Mesopotamia's relationship with this strategic highland-lowland transitional zone and with the unique opportunity to explore, through a broad range of archaeological data, the nature of this Babylonian presence in, and engagement with, the local landscape and its inhabitants.

The data presented here, though preliminary, already demand a fundamental reconceptualization of the Diyala valley during the Late Bronze Age and, in

\footnotetext{
${ }^{142}$ Delougaz 1952, 148-50.

${ }^{143}$ McMahon 2005, 72-3, Type C16b, 110.

${ }^{144}$ Bürger and Miglus 2016, 22, fig. 1 .

${ }^{145}$ Bürger and Miglus 2016, 28.

${ }^{146}$ Bürger and Miglus 2016, 29.
} 


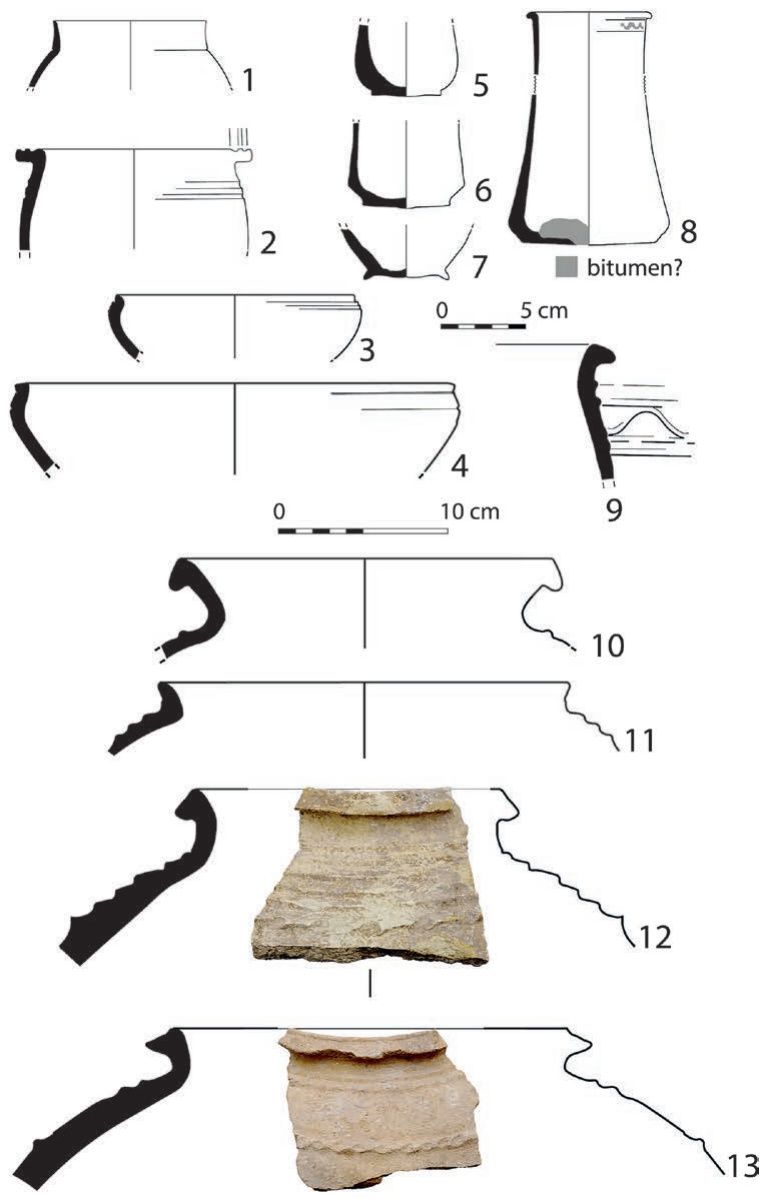

FIG. 21. Ceramics from SRP 94, trench K136: 1, 2, small jars; 3, 4, bowls; 5-8, beakers; 9-13, large jars.

addition, the chronology and spatiality of Babylonian expansionism. Both Adams' Land Behind Baghdad ${ }^{147}$ and later surveys and excavations in the Hamrin ${ }^{148}$ have characterized the Late Bronze Age as a period of dramatic settlement reduction and ruralization. The results of the Sirwan Regional Project, by contrast, reveal a very different settlement landscape in which the fertile plains on either side of the Diyala were dominated by large and often newly established urban centers. These were situated along major north-south thoroughfares, where the river cuts across the Jebel Mirwari and on the Jebel's eastern edge overlooking the narrowing passage between the Khani Masi plain and the modern town of Khanaqin. The surface assemblages of these urban centers unambiguously point to strong
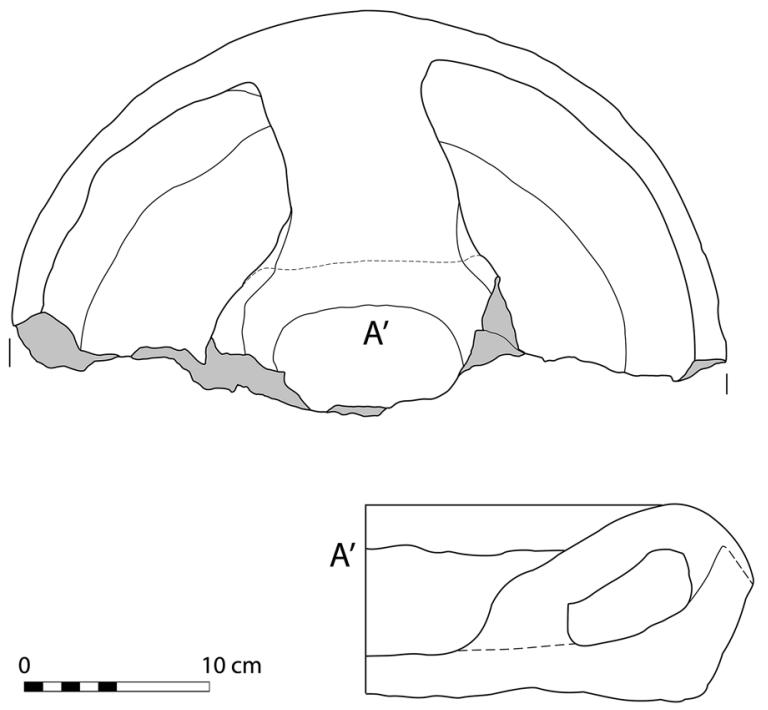

FIG. 22. Ceramic tray with internal handles from locus 6 in trench K136 on SRP 94.

and varied connections with Babylonia. The evidence for connections with Babylonia, however, diminish rapidly farther to the north of this strategic perimeter.

Ongoing research at the largest of these sites, the Khani Masi cluster, has thus far revealed an extensive, at least 40 ha, Late Bronze Age settlement with two phases of monumental architecture, evidence for industrial production, and a cultural repertoire that matches closely, and across a range of categories, Kassite cities in Mesopotamia and the more modest communities in the Hamrin. This includes Khani Masi's ceramic repertoire, the range of attested burial practices, funerary locales, and some ritual paraphernalia. The tendency toward trapezoidal building plans in the mudbrick phase (phase 1) also finds parallels in the Hamrin, ${ }^{149}$ while masonry techniques and brick sizes in the subsequent baked brick phase (phase 4) are broadly comparable to those of monumental buildings in Mesopotamia's great cities. At the same time, idiosyncrasies in cultural practice and production have emerged from our data. The production of the site's otherwise classic Babylonian ceramic repertoire includes diverging forming techniques and problem solving to prevent the cracking of goblet bases. ${ }^{150}$ The relief offering stand, the ritual assemblages with faience buckets not associated with burials, and the culinary

\footnotetext{
${ }^{147}$ Adams 1965.

${ }^{148}$ Boehmer and Dämmer 1985, 33.
}

\footnotetext{
${ }^{149}$ Boehmer and Dämmer 1985, 28, 30.

${ }^{150}$ Glatz and Casana 2016.
} 
preferences of Khani Masi's inhabitants also point toward a regional cultural tradition nested within a broadly Babylonian milieu. Overall, with the evidence unearthed to date, it is difficult not to interpret Khani Masi as a new Babylonian foundation. Khani Masi’s geographical location close to the left bank of the Diyala makes it a plausible candidate for a city known from texts, either Padan or indeed Halman if we assume that the scribe of the Sarpol-e Zohab kudurru did not mistake the Alwand for the Diyala/Turran.

Absolute dates obtained from Khani Masi broadly tally with Agum's claim of sovereignty over Halman and Padan. They suggest a date in the 15 th or possibly even the late 16th century B.C.E. for the earliest largescale mudbrick architecture exposed so far on SRP 46 and a date in the 13th century for the destruction of the monumental structure in trench Y88. Based on radiocarbon determinations, the latest probable terminus post quem for construction of the final phase of the baked-brick structure in Z86 is ca. cal B.C.E. $1233(2 \sigma)$.

Our work is beginning to reveal the kind of complex, noncontiguous spatiality one would expect of early imperial political landscapes. ${ }^{151}$ In this case, we have unambiguous cultural and textual evidence for a connection to the Kassite political realm in the Hamrin region from the 13 th and 12 th centuries B.C.E. only. Tell Yelkhi, despite being occupied in the 15th and 14th centuries and a regional center then also, shows only limited cultural connections with Babylonia at that time. ${ }^{152}$ Although we currently lack comparable textual evidence at Khani Masi, the site's strong Babylonian cultural connections stretch back over 200 years before the Hamrin sites as well as overlap with them, while its monumental buildings, each of which is of the same scale as the palazzo at Yelkhi, leave little doubt about the official nature of their function.

Thus, it is tempting to associate Khani Masi with the expansion and long-term consolidation of the Kassite imperial network along the Upper Diyala. However, the link between cultural identity and political affiliation, while seemingly likely in this specific case, is still to be established empirically. We have yet to tease from present results and data from future seasons whether, how, and to what degree Khani Masi and its neighbor-

\footnotetext{
${ }^{151}$ For discussion of discontinuous territorialities, see, e.g. Smith 2003

${ }^{152}$ Supra n. 52.
}

ing sites were implicated in the reproduction of the Kassite imperial network, the responses this elicited from local communities, and the long-term consequences of this encounter.

\section{CONCLUSION}

The critical new data presented in this paper and the results of our ongoing analyses have begun to fundamentally alter our understanding of the Upper Diyala region and its relationships with Babylonia. As such, they present a first step toward a local, bottom-up, and archaeological narrative of Babylonia's ongoing encounter with the Zagros and its transitional landscapes.

To this end, our ongoing excavations at Khani Masi will focus on the identification and exploration of evidence for Old Babylonian occupation at the site in order to trace diachronically the area's evolving relationship with central Mesopotamia. We also plan to track social differences among Khani Masi's Late Bronze Age inhabitants and their respective cultural identities by investigating habitation areas at some distance from the monumental structures excavated to date. Through ongoing and future analyses, including organic residue work, ceramic production analyses, and stable isotope studies of human and animal movements, we aim to follow threads of local practice and potential links, hitherto difficult to detect, with the Zagros highlands.

\author{
Claudia Glatz \\ Archaeology \\ School of Humanities \\ University of Glasgow \\ Glasgow G12 8QQ \\ United Kingdom \\ Claudia.glatz@glasgow.ac.uk \\ Jesse Casana \\ Department of Anthropology \\ Dartmouth College \\ Hanover, New Hampshire 03755 \\ Jesse.j.casana@dartmouth.edu
}

Robin Bendrey, University of Edinburgh
Emma Baysal, Trakya University
Daniel Calderbank, University of Glasgow
Francesca Chelazzi, University of Glasgow
Francesco Del Bravo, Freie Universität Berlin
Neil Erskine, University of Glasgow
Mette Marie Hald, National Museum of Denmark
Elise Jakoby Laugier, Dartmouth College
Eric Jensen, University of Arkansas
Elsa Perruchini, University of Glasgow

Robin Bendrey, University of Edinburgh

Emma Baysal, Trakya University

Daniel Calderbank, University of Glasgow

Francesca Chelazzi, University of Glasgow

Francesco Del Bravo, Freie Universität Berlin

Neil Erskine, University of Glasgow

Elise Jakoby Laugier, Dartmouth College

Elsa Perruchini, University of Glasgow 


\section{Works Cited}

Abdi, K., and G.M. Beckman. 2007. "An Early Second-Millennium Cuneiform Archive from Choga Gavaneh." JCS 59:39-51.

Adams, R.M. 1965. Land Behind Baghdad: A History of Settlement on the Diyala Plains. Chicago and London: University of Chicago Press.

Akkermans, P.M.M.G., R. Cappers, C. Cavallo, O. Nieuwenhuyse, B. Nilhamn, and I.N. Otte. 2006. "Investigating the Early Pottery Neolithic of Northern Syria: New Evidence from Tell Sabi Abyad." AJA 110(1):123-56.

Al-Rawi, F.N.H. 1994. "Texts from Tell Haddad and Elsewhere." Iraq 56:35-43.

Alster, B. 1972. "'Ninurta and the Turtle,' UET 6/12." JCS 24(4):120-25.

Altaweel, M., A. Marsh, S. Mühl, O. Nieuwenhuyse, K. Radner, K. Rasheed, and S.A. Saber. 2012. "New Investigations in the Environment, History and Archaeology of the Iraqi Hilly Flanks: Sharizor Survey Project 2009-2011.” Iraq 74:1-36.

Annus, A. 2001. The Standard Babylonian Epic of Anzu. State Archives of Assyria Cuneiform Texts 3. Helsinki: The NeoAssyrian Text Corpus Project.

Armstrong, J.A. 1981a. "Pottery from Tell Ahmed al-Mughir and Tell Ajamat." In Uch Tepe I: Tell Razuk, Tell Ahmed alMughir, Tell Ajamat, edited by M. Gibson, 151-56. Baghdad: State Organisation of Antiquities and Heritage.

. 1981b. "Tell Ajamat." In Uch Tepe I: Tell Razuk, Tell Ahmed al-Mughir, Tell Ajamat, edited by M. Gibson, 147-50. Baghdad: State Organisation of Antiquities and Heritage.

_. 1993. "Pottery." In Nippur III: Kassite Buildings in Area WC-1, edited by R.L. Zettler, 67-80. Chicago: Chicago University Press.

_ 2017. "Babylonian Pottery in the Kassite Period." In Karduniaš: Babylonia Under the Kassites. Proceedings of the Symposium Held in Munich 30 Juni to 2 July 2011, 2 vols., edited by A. Bartelmus and K. Sternitzke, 2:421-36. UAVA 11.2. Berlin: De Gruyter.

Armstrong, J.A., and H. Gasche. 2014. Mesopotamian Pottery: A Guide to the Babylonian Tradition in the Second Millennium B.C. Ghent and Chicago: University of Ghent and the Oriental Institute of the University of Chicago.

Bartelmus, A.. and K. Sternitzke. 2017. Karduniaš: Babylonia Under the Kassites: Proceedings of the Symposium Held in Munich 30 June to 2 July 2011. 2 vols. UAVA 11.1, 11.2. Boston: De Gruyter.

Bergamini, G., C. Saporetti, and L. Constantini. 1985. “Tell Yelkhi." In La terra tra i due fiumi: Venti anni di archeologia italiana in Medio Oriente. La Mesopotamia dei tesori, edited by E. Quarantelli, 41-60. Turin: Il Quadrante Edizioni.

Black, J., and A. Green. 1992. Gods, Demons and Symbols of Ancient Mesopotamia. London: British Museum Press.

Black, J.A., G. Cunningham, J. Ebeling, E. Flückiger-Hawker, E. Robson, J. Taylor, and G. Zólyomi. 2006. The Electronic Text Corpus of Sumerian Literature. http://etcsl.orinst. ox.ac.uk/.
Boehmer, R.M., and H.-W. Dämmer. 1985. Tell Imlihiye, Tell Zubeidi, Tell Abbas. Mainz am Rhein: Philipp von Zabern.

Boessneck, J. 1993. "Appendix A. Tierknochenfunde aus Nippur: 13. Saison.” In Nippur III: Kassite Building in Area WC-1, edited by R.L. Zettler, 269-98. Chicago: Oriental Institute of the University of Chicago.

Boessneck, J., and M. Kokabi. 1993. "Appendix B. Tierknochenfunde aus Nippur: 14. Saison." In Nippur III: Kassite Building in Area WC-1, edited by R.L. Zettler, 299-340. Chicago: Oriental Institute of the University of Chicago.

Borger, R. 1970. "Vier Grenzsteinurkunden Merodachbaladans I." Altorientalische Forschungen 23:1-26.

Brinkman, J.A. 1976. Materials and Studies for Kassite History. Vol. 1, pt. A, Catalogue of Cuneiform Sources Pertaining to Specific Monarchs of the Kassite Dynasty. Chicago: Chicago University Press.

2017. "Babylonia Under the Kassites: Some Aspects for Consideration." In Karduniaš: Babylonia Under the Kassites. Proceedings of the Symposium Held in Munich 30 Juni to 2 July 2011, 2 vols., edited by A. Bartelmus and K. Sternitzke, 1:1-44. UAVA 11.1. Berlin: De Gruyter.

Bryce, T. 2003. Letters of the Great Kings of the Ancient Near East: The Royal Correspondence of the Late Bronze Age. Abingdon, Oxon, and New York: Routledge.

Bürger, U., and P. Miglus. 2016. "Internal-Handled Bowls: Puzzling Pots from Bronze Age Mesopotamia." In Parcours d'Orient: Recueil de textes offert à Christine Kepinksi, edited by B. Perello and A. Tenu, 21-34. Oxford: Archaeopress.

Calderbank, D. 2018. "Moulding Clay to Model Sealand Society: Pottery Production and Function at Tell Khaiber, Southern Iraq.” Ph.D. diss., University of Manchester.

Campbell, S., J. Moon, and R. Killick. 2017. “Tell Khaiber: An Administrative Centre of the Sealand Period.” Iraq 79:21-46.

Carter, L., and M. Stolper. 1984. Elam: Surveys of Political History and Archaelogy. Los Angeles: University of California Press.

Casana, J., and C. Glatz. 2017. "The Land Behind the Land Behind Baghdad: Archaeological Landscapes of the Upper Diyala (Sirwan) River Valley." Iraq 79:47-69.

Casana, J., A. Wiewel, A. Cool, A.C. Hill, K.D. Fisher, and E.J. Laugier. 2017. "Archaeological Aerial Thermography in Theory and Practice." Advances in Archaeological Practice 5(4):310-27.

Charpin, D. 2004. "Histoire politique du Proche-Orient Amorrite (2002-1595).” In Mesopotamien: Die altbabylonische Zeit, edited by D. Charpin, D.O. Edzard, and M. Stol, 1-480. Fribourg and Göttingen: Universitätsverlag, Vandenhoeck and Ruprecht.

- 2019. "Tu es de mon sang": Les alliances dans le ProcheOrient ancient. Paris: Collège de France Les Belles Lettres.

Clayden, T. 1998. "Faience Buckets." BaM 29:47-72.

Clutton-Brock, J. 2001. "Identifications of the Animal Remains." In Excavations at Tepe Guran in Luristan: The Bronze and Iron Age Periods, edited by H. Thrane, 133-38. Moesgaard, Denmark: Jutland Archaeological Society.

Dalley, S. 1985. "Foreign Chariotry and Cavalry in the Armies of Tiglath-Pileser III and Sargon II.” Iraq 47:31-48. 
1989. Myths from Mesopotamia: Creation, the Flood, Gilgamesh, and Others. Oxford: Oxford University Press.

Delougaz, P. 1952. Pottery from the Diyala Region. Chicago: Chicago University Press.

Duistermaat, K. 2008. The Pots and Potters of Assyria: Technology and Organisation of Production, Ceramic Sequence, and Vessel Function at Late Bronze Age Tell Sabi Abyad, Syria. Turnhout, Belgium: Brepols.

Dunham, S. 1993. "Beads for Babies.” ZA 83:237-57.

Fiorina, P. 1984. "Excavation at Tell Hassan: Preliminary Report." Sumer 40:227-89.

Foster, B. 2005. Before the Muses: An Anthology of Akkadian Literature. 3 rd ed. Bethesda, Md.: CDL Press.

Frayne, D. 1992. The Early Dynastic List of Geographical Names. New Haven: American Oriental Society.

_. 2008. "The Zagros Campaigns of the Ur III Kings." Journal of the Canadian Society for Mesopotamian Studies 3:33-56.

Fuchs, A. 2011. "Das Osttigrisgebiet von Agum II. bis zu Darius I. (ca. 1500-500 BC)." In Between the Cultures: The Central Tigris Region from the 3 rd to the 1st Millennium BC, edited by P. Miglus and S. Mühl, 229-320. Heidelberg: Heidelberger Orientverlag.

_ 2017. "Die Kassiten, das mittelbabylonische Reich und der Zagros." In Karduniaš: Babylonia Under the Kassites. Proceedings of the Symposium Held in Munich 30 Juni to 2 July 2011, 2 vols., edited by A. Bartelmus and K. Sternitzke, 1:123-65. UAVA 11.1. Berlin: De Gruyter.

Gasche, H. 1989. La Babylonie au 17e siècle avant notre ère: Approche archéologique, problèmes et perspectives. Ghent: University of Ghent.

Gasche, H., J.A. Armstrong, S.W. Cole, and V.G. Gurzadyan. 1998. Dating the Fall of Babylon: A Reappraisal of Second-Millennium Chronology. Ghent and Chicago: MHE Memoirs.

Gates, M.-H. 1988. "Dialogues Between Ancient Near Eastern Texts and the Archaeological Record: Test Cases from Bronze Age Syria.” BASOR 270:63-91.

Gentili, P. 2012. "Some Notes Between Yelkhi and 'Dating." Mesopotamia 47:103-12.

George, A. 2003. The Epic of Gilgamesh. London: Penguin.

Glassner, J.-J. 2005. Mesopotamian Chronicles. Leiden: Brill.

Glatz, C., and J. Casana. 2016. "Of Highland-Lowland Borderlands: Local Societies and Foreign Power in the ZagrosMesopotamian Interface." JAnthArch 44(Part A):127-47.

Grayson, A.K. 1975. Assyrian and Babylonian Chronicles. Locust Valley, N.Y.: J.J. Augustin.

Grigson, C. 2007. "Culture, Ecology and Pigs from the Fifth to the Third Millennium BC Around the Fertile Crescent." In Pigs and Humans: 10,000 Years of Interaction, edited by U. Albarella, K. Dobney, A. Ervynck, and R. RowleyConwy, 83-108. Oxford: Oxford University Press.

Haenrick, E., and B. Overlaet. 2010. "Bronze and Iron Age Pottery from the Ilam Graveyard (Pusht-i Kuh, Iran).” IrAnt 45:277-304.

Hallo, W.W. 1957-1971. “Gutium.” RLA 3:708-20.

Haussperger, M., B. Hrouda, and E. Strommenger. 1981. “Gula-Tempel 1975-1978 (4.-6. Kampagne).” In Isin-Išān Bahrīyāt II: Die Ergebnisse der Ausgrabungen 1975-1978, edited by B. Hrouda, 9-25. Munich: Verlag der Bayrischen Akademie der Wissenschaften.

Hilzheimer, M. 1941. Animal Remains from Tell Asmar. Chicago: The Oriental Institute of the University of Chicago.

Invernizzi, A. 1980. "Excavations in the Yelkhi Area (Hamrin Project, Iraq)." Mesopotamia 15:19-49.

Kaniuth, K. 2017. “Isin in the Kassite Period.” In Karduniaš: Babylonia Under the Kassites. Proceedings of the Symposium Held in Munich 30 Juni to 2 July 2011, 2 vols., edited by A. Bartelmus and K. Sternitzke, 2:492-507. UAVA 11.2. Berlin: De Gruyter.

Kessler, K. 1982. “Kassitische Tontafeln vom Tell Imliyeh.” BaM 13:51-116.

. 1985a. "Die Tontafeln." In Tell Imlihiye, Tell Zubeidi, Tell Abbas, edited by R.M. Boehmer and H.-W. Dämmer, 74-9. Mainz: Philipp von Zabern.

1985b. "Zu den Tontafeln." In Tell Imlihiye, Tell Zubeidi, Tell Abbas, edited by R.M. Boehmer and H.-W.Dämmer, 18-19. Mainz: von Zabern.

Killik, R.G. 1988. Tell Rubeidheh: An Uruk Village in the Jebel Hamrin. London: British School of Archaeology in Iraq and Directorate of Antiquities, Baghdad.

Kordevani, M. 1971. "Excavations at Chogha Gavaneh." Bastan Chenassi va Honar-e Iran 7-8:36-71.

Kuhrt, A. 1995. The Ancient Near East ca.3000-330 BC. Vol. 1. London: Routledge.

Lambert, W.G. 1984. "Review of Studies in Marduk." BSOAS 47(1):1-9.

. 2007. Babylonian Oracle Questions. Winona Lake, Ind.: Eisenbrauns.

-2018. Babylonian Creation Myths. Winona Lake, Ind.: Eisenbrauns.

Legrain, L. 1922. Historical Fragments. Philadelphia: University Museum.

Liverani, M. 2001. International Relations in the Ancient Near East, 1600-1100 BC. New York: Palgrave.

- 2011. The Ancient Near East: History, Society and Economy. Abingdon, Oxon: Routledge.

Lloyd, S. 1943. Twin Rivers: A Brief History of Iraq from the Earliest Times to the Present Day. London: Oxford University Press.

Mallowan, M.E.L. 1946. "Excavations in the Balikh Valley, 1938." Iraq 8:111-59.

Manning, S.W., C.B. Griggs, B. Lorentzen, G. Barjamovic, C.B. Ramsey, B. Kromer, and E.M. Wild. 2016. "Integrated Tree-Ring-Radiocarbon High-Resolution Timeframe to Resolve Earlier Second Millennium BCE Mesopotamian Chronology." PLoS ONE, 13 July, 11(7). https:// doi.org/10.1371/journal.pone.0157144.

McMahon, A. 2005. Nippur. Vol. 5, The Early Dynastic to Akkadian Transition. The Area WF Sounding at Nippur. Chicago: The Oriental Institute of the University of Chicago.

Miglus, P.A., U. Bürger, R.A. Fenter, S. Mühl, and A. Sollee. 2013. "Excavations at Bakr Awa 2010 and 2011." Iraq 75:43-88.

Moorey, P.R.S. 1994. Ancient Mesopotamian Materials and Industries: The Archaeological Evidence. Winona Lake, Ind.: Eisenbrauns. 
Moran, L.W. 1992. The Amarna Letters. Baltimore: The Johns Hopkins University Press.

Muhamed, A.K. 1992. Old Babylonian Cuneiform Texts from the Hamrin Basin. London: Nabu.

Nielsen, K. 2018. The Reign of Nebuchadnezzar I in History and Historical Memory. London: Routledge.

Nissen, E., M. Tatar, J.A. Jackson, and M.B. Allen. 2011. "New Views on Earthquake Faulting in the Zagros Foldand-Thrust Belt of Iran." Geophysical Journal International 186(3):928-44.

Oselini, V. 2018. “The Cultural Influence of Mesopotamian States in the Upper and Middle Course of the Diyala River During the Mid-2nd Millennium BC." In Proceedings of the 10th ICAANE in Vienna, edited by F. Höflmayer, 391-403. Wiesbaden: Harrassowitz.

Overlaet, B. 2005. "The Chronology of the Iron Age in the Pusht-i Kuh, Lurestan.” IrAnt 40:1-33.

Paulus, S. 2011. "Foreigners and Foreign Rulers: The Case of Kassite Babylonia (2nd Half of the 2nd Millennium B.C.E)." In The Foreigner and the Law: Perspectives from the Hebrew Bible and the Ancient Near East, edited by R. Archenbach, A. Rainer, and J. Wöhrle, 1-16. Wiesbaden: Harrassowitz.

_. 2013. "The Limits of Middle Babylonian Archives." In Archives and Archival Documents in Ancient Societies: Legal Documents in Ancient Societies IV, Trieste 30 September-1 October 2011, edited by M. Faraguna, 87-103. Trieste: EUT Edizioni Università di Trieste.

—. 2014a. "Babylonien in der 2. Hälfte des 2. Jts. v. Chr.: (K)ein Imperium? Ein Überblick über Geschichte und Struktur des mittelbabylonischen Reiches (ca. 15001000 B.C.)." In Imperien und Reiche der Weltgeschichte, edited by M. Gehler and R. Rollinger, 65-100. Wiesbaden: Harrassowitz.

. 2014b. Die babylonischen Kudurru-Inschriften von der kassitischen bis zur frühneubabylonischen Zeit: Untersucht unter besonderer Berücksichtigung gesellschafts- und rechtshistorischer Fragestellungen. Münster: Ugarit-Verlag.

___ 2017. "The Babylonian Kudurru Inscriptions and Their Legal and Sociohistorical Implications." In Karduniaš: Babylonia Under the Kassites. Proceedings of the Symposium Held in Munich 30 Juni to 2 July 2011, 2 vols., edited by A. Bartelmus and K. Sternitzke, 1:229-44. UAVA 11.1. Berlin: De Gruyter.

2018. "Fraud, Forgery, and Fiction: Is There Still Hope for Agum-Kakrime?” JCS 70:115-66.

Perruchini, E., C. Glatz, M.M. Hald, J. Casana, and J.L. Toney. 2018. "Revealing Invisible Brews: A New Approach to the Chemical Identification of Ancient Beer." JAS 100:176-90.

Pfälzner, P. 2007. "The Late Bronze Age Ceramic Traditions of the Syrian Jazirah." In Céramique de l'âge du bronze en Syrie. Vol. 2, L'Euphrate et la région de Jézireh, edited by M. al-Maqdissī, V. Matoïan, and C. Nicolle, 231-91. Beirut: Bibliothèque archéologique et historique.

Podany, A.H. 2012. Brotherhood of Kings: How International Relations Shaped the Ancient Near East. Oxford: Oxford University Press.

Pons, N., and H. Gasche. 2006. "Du Cassite dans les Monts
Zagros." In Les espaces syro-mésopotamiens: Dimensions de l'expérience humaine au Proche-Orient ancien. Volume d'hommage offert à Jean-Claude Margueron, edited by P. Butterlin, M. Lebeau, J.-Y. Monchambert, J.L. Montero Fenollos, and B. Muller, 375-85. Turnhout, Belgium: Brepols.

Postgate, J.N. 1984. “The Historical Geography of the Hamrin Basin." Sumer 40:149-59.

Radner, K. 2003. "An Assyrian View on the Medes." In Continutity of Empire (?): Assyria, Media, Persia, edited by G.B. Lanfranchi, M. Roaf, and R. Rollinger, 37-64. Padua: Sargon.

2014. "Zagros Spice Mills: The Simurrean and the Hašimur Grindstones." In From Source to History: Studies on Ancient Near Eastern Worlds and Beyond Dedicated to Giovanni Battista Lanfranchi on the Occasion of His 65th Birthday on June 23, 2014, edited by S. Gaspa, A. Greco, D. Morandi Bonacossi, S. Ponchia, and R. Rollinger, 573-80. Münster: Ugarit-Verlag.

Roaf, M. 2017. "Kassite and Elamite Kings.” In Karduniaš: Babylonia Under the Kassites. Proceedings of the Symposium Held in Munich 30 Juni to 2 July 2011, 2 vols., edited by A. Bartelmus and K. Sternitzke, 1:166-95. UAVA 11.1. Berlin: De Gruyter.

Rouault, O., and C. Saporetti. 1985. "Old Babylonian Texts from Tell Yelkhi (Hamrīn Project, Iraq).” Mesopotamia 20:23-52.

Sassmannshausen, L. 1999. "The Adaptation of the Kassites to the Babylonian Civilisation." In Languages and Cultures in Contact, edited by K. van Lerberghe and G. Voet, 409_ 24. Leuven: Peeters.

Seidl, U. 1989. Die babylonischen Kudurru-Reliefs: Symbole mesopotamischer Gottheiten. Freiburg: Universitäts-Verlag.

_ 2017. "Babylonische Kunst zur Kassitenzeit." In Karduniaš: Babylonia Under the Kassites. Proceedings of the Symposium Held in Munich 30 Juni to 2 July 2011, 2 vols., edited by A. Bartelmus and K. Sternitzke, 2:313-32. UAVA 11.2. Berlin: De Gruyter.

Smith, A. 2003. The Political Landscape: Constellations of Authority in Early Complex Polities. Los Angeles: University of California Press.

Sommerfeld, W. 1982. Der Aufstieg Marduks: Die Stellung Marduks in der babylonischen Religion des zweiten Jahrtausends v. chr. Kevelaer: Butzon und Bercker.

Steinkeller, P. 1981. "Early History of the Hamrin Basin in the Light of Textual Evidence." In Uch Tepe I: Tell Razuk, Tell Ahmed al-Mughir, Tell Ajamat, edited by M. Gibson, 163-68. Chicago: University of Chicago Press.

2013. "Puzur-Inšušinak at Susa: A Pivotal Episode of Early Elamite History Reconsidered." In Susa and Elam: Archaeological, Historical and Geographical Perspectives, edited by D. Graef and J. Tavernier, 293-317. Leiden: Brill.

Sternitzke, K. 2017. "Bestattungen in der Kassiten- und Isin II-Zeit. In Karduniaš: Babylonia Under the Kassites. Proceedings of the Symposium Held in Munich 30 Juni to 2 July 2011,2 vols., edited by A. Bartelmus and K. Sternitzke, 2:351-420. UAVA 11.2. Berlin: De Gruyter. 
Stol, M. 1976. Studies in Old Babylonian History. Leiden: Nederlands Historisch Archaeologisch Instituut.

Stone, E.C. 1977. "Economic Crisis and Social Upheaval in Old Babylonian Nippur." In Mountains and Lowlands: Essays in the Archaeology of Greater Mesopotamia, edited by L.D. Levine and T.C. Young, 267-89. Malibu: Undena.

Talon, P. 2005. The Standard Babylonian Creation Myth: Enūma Eliš. Helsinki: The Neo-Assyrian Text Corpus Project.

Tenney, J.S. 2011. Life at the Bottom of Babylonian Society: Servile Laborers at Nippur in the 14th and 13th Centuries B.C. Leiden: Brill.

. 2016. "The Elevation of Marduk Revisited: Festivals and Sacrifices at Nippur during the High Kassite Period”. JCS 68: 153-80.

Thrane, H. 1999. "Pots and Peoples_Once Again: The Goblets from the Bronze Age Settlement at Tepe Guran, Lurestan." IrAnt 34:21-40.

- 2001. Excavations at Tepe Guran in Luristan: The Bronze and Iron Age Periods. Moesgaard, Denmark: Jutland Archaeological Society.

Valtz, E. 1985. “La campagna di Yelkhi.” In La terra tra i due fiumi: Venti anni di archeologia in Medio Oriente. La Mesopotamia dei Tesori, edited by E. Quarantelli, 69-71. Turin: Il Quadrante Edizioni.

_.2002-2003. "La ceramica dei livelli II e I." In La ceramica di Tell Yelkhi, edited by G. Bergamini, A. Gabutti, and E. Valtz. Mesopotamia 37-38:265-320.

van As, A., and J. Jacobs. 2014. “The Babylonian Potter: Environment, Clay and Techniques." In Mesopotamian Pottery: A Guide to the Babylonian Tradition in the Second Millennium B.C., edited by J.A. Armstrong and H. Gasche, 75-83. Chicago: Oriental Institute of the University of Chicago. van Dijk, J. 1983. LUGAL UD ME-LÁM-bi NIR-GAL: Le récit épique et didactique des Travaux de Ninurta, du Déluge et de la Nouvelle Création. 2 vols. Leiden: Brill.

van Ess, M. 2014. "Characteristics of Middle Babylonian Pottery Production as Mirrored on Old Babylonian PotteryContinuity or Change?" In Recent Trends in the Study of
Late Bronze Age Ceramics in Syro-Mesopotamia and Neighbouring Regions: Proceedings of the International Workshop in Berlin, 2-5 November 2006, edited by M. Luciani and A. Hausleiter, 333-83. Rahden: Leidorf.

van Koppen, F. 2006. “The Agum-Kakrime Inscription.” In The Ancient Near East: Historical Sources in Translation, edited by M.W. Chavalas, 135-39. Malden, Mass.: Blackwell.

_. 2017. “The Early Kassite Period.” In Karduniaš: Babylonia Under the Kassites. Proceedings of the Symposium Held in Munich 30 Juni to 2 July 2011, 2 vols., edited by A. Bartelmus and K. Sternitzke, 1:45-92. UAVA 11.1. Berlin: De Gruyter.

Wiggerman, F.A.M. 1995. "Mušhuuššu.” RLA 8:455-62.

Woolley, L. 1934. Excavations at Ur. Vol. 2, The Royal Cemetery. London: Trustees of the British Museum and $\mathrm{Mu}$ seum of the University of Pennsylvania.

. 1965. Ur Excavations. Vol. 3, The Kassite Period and the Period of the Assyrian Kings. London: Trustees of the British Museum and Museum of the University of Pennsylvania.

Wygnańska, Z., and D. Bar-Yosef Mayer. 2018. “Beads.” In Associated Regional Chronologies for the Ancient Near East and the Eastern Mediterranean: Artefacts, edited by M. Lebeau, 283-94. Turnhout, Belgium: Brepols.

Yaseen, G.T. 1995. Old Babylonian Pottery from the Hamrin: Tell Halawa. London: NABU.

Young, T.C., Jr. 1969. Excavations at Godin Tepe: First Progress Report. Toronto: The Royal Ontario Museum.

Young, T.C., Jr., and D.L. Levine. 1974. Excavations of the Godin Project: Second Progress Report. Toronto: Royal Ontario Museum.

Zadok, R. 1978. "Peoples from the Iranian Plateau in Babylonia During the Second Millennium B.C.” Iran 25:1-26.

Zarnkow, M., A. Otto, and B. Einwag. 2011. "Interdisciplinary Investigations into the Brewing Technology of the Ancient Near East and the Potential of the Cold Mashing Process." In Liquid Bread: Beer and Brewing in Cross-cultural Perspective, edited by W. Schiefenhövel and $\mathrm{H}$. Macbeth, 47-54. Oxford: Berghahn. 